\title{
Genome-Wide Analysis of OPR Family Genes in Cotton Identified a Role for GhOPR9 in Verticillium dahliae Resistance
}

\author{
Shichao Liu ${ }^{1,2}$, Ruibin Sun ${ }^{1}$, Xiaojian Zhang ${ }^{3}$, Zili Feng $^{1}{ }^{1}$, Feng Wei ${ }^{1,3}$, Lihong Zhao ${ }^{1}$, \\ Yalin Zhang ${ }^{1}$, Longfu Zhu ${ }^{2}{ }^{1}$, Hongjie Feng ${ }^{3, *}$ and Heqin Zhu ${ }^{1,3, *}$ \\ 1 State Key Laboratory of Cotton Biology, Institute of Cotton Research of Chinese Academy of \\ Agricultural Sciences, Anyang 455000, China; liushichao29@163.com (S.L.); sunruibin@caas.cn (R.S.); \\ fengzili@caas.cn (Z.F.); weifeng0108@163.com (F.W.); zhaolihongqq@163.com (L.Z.); \\ yalinzhang2012@163.com (Y.Z.) \\ 2 College of Plant Science and Technology, Huazhong Agricultural University, Wuhan 430070, China; \\ lfzhu@mail.hzau.edu.cn \\ 3 Zhengzhou Research Base, State Key Laboratory of Cotton Biology, School of Agricultural Sciences, \\ Zhengzhou University, Zhengzhou 450001, China; xiaojianzhang993@163.com \\ * Correspondence: fenghongjie@caas.cn (H.F.); zhuheqin@caas.cn (H.Z.); Tel.: +86-372-256-2280 (H.Z.)
}

Received: 12 August 2020; Accepted: 24 September 2020; Published: 27 September 2020

\begin{abstract}
The 12-oxo-phytodienoic acid reductases (OPRs) have been proven to play a major role in plant development and growth. Although the classification and functions of OPRs have been well understood in Arabidopsis, tomato, rice, maize, and wheat, the information of OPR genes in cotton genome and their responses to biotic and abiotic stresses have not been reported. In this study, we found 10 and 9 OPR genes in Gossypium hirsutum and Gossypium barbadense, respectively. They were classified into three groups, based on the similar gene structure and conserved protein motifs. These OPR genes just located on chromosome 01, chromosome 05, and chromosome 06. In addition, the whole genome duplication (WGD) or segmental duplication events contributed to the evolution of the OPR gene family. The analyses of cis-acting regulatory elements of GhOPRs showed that the functions of OPR genes in cotton might be related to growth, development, hormone, and stresses. Expression patterns showed that GhOPRs were upregulated under salt treatment and repressed by polyethylene glycol 6000 (PEG6000). The expression patterns of GhOPRs were different in leaf, root, and stem under $V$. dahliae infection. GhOPR9 showed a higher expression level than other OPR genes in cotton root. The virus-induced gene silencing (VIGS) analysis suggested that knockdown of GhOPR9 could increase the susceptibility of cotton to $V$. dahliae infection. Furthermore, GhOPR9 also modulated the expressions of jasmonic acid (JA) pathway-regulated genes under the $V$. dahliae infection. Overall, our results provided the evolution and potential functions of the OPR genes in cotton. These findings suggested that GhOPR9 might play an important role in cotton resistance to $V$. dahliae.
\end{abstract}

Keywords: OPR; cotton; gene family; Verticillium dahliae; VIGS

\section{Introduction}

In plants, jasmonic acid (JA) is a lipid-derived signaling phytohormone and activates defense against various stresses, such as insects, pathogen, salt, temperature, and wounding [1,2]. Besides, it also contributes to modulating plant growth and development, such as seed germination, tendril coiling, pollen maturation, fruit ripening, and root growth [3,4]. Furthermore, the JA signal pathway combines with the salicylic acid (SA) signal pathway, ethylene (ET) signal pathway, and abscisic acid (ABA) signal pathway to form a complex network [5-7]. 
Jasmonic acid biosynthesis is originated from $\alpha$-linolenic, followed by the function of lipoxygenase (LOX), allene oxide synthase (AOS), and allene oxide cyclase (AOC) to form 12-oxophytodienoic acid (OPDA) via the octadecanoic pathway [8-10]. OPRs are the key enzyme to catalyze the conversion from OPDA to 12-oxo-phytodienoic acid (OPC-8:0), a reaction that is a key process of JA biosynthesis [11,12]. OPR genes belong to the old yellow enzyme (OYE) family. They are categorized as flavin mononucleotide (FMN)-dependent oxidoreductases. The Pfam analysis revealed that Oxidored_FMN (ID:PF00724) was the specific domain in OPR proteins. The OPR was first purified from cell cultures of Corydalis sempervirens, and the first OPR homologous gene in a plant was cloned from Arabidopsis thaliana [13]. There were three OPR genes in A. thaliana: AtOPR1, AtOPR2, and AtOPR3. They were classified into two groups-group I (OPRI) and group II (OPRII)—based on their different substrates. AtOPR1 and AtOPR2 were classified into group I, catalyzed 9R,13R-OPDA, which is not related to JA biosynthesis. The AtOPR3 (OPRII) preferentially catalyzed 9S,13S-OPDA, an intermediate precursor of JA biosynthesis. A previous study showed that AtOPR3 was the only enzyme of OPR to reduce the correct stereoisomer of OPDA to produce JA required for male gametophyte development [14].

Subsequently, OPR genes were identified in dicots and monocots, such as pea [15], maize [16], tomato [17], tea [18], rice [19], and wheat [20]. In contrast to dicots, the OPR genes were classified into five subgroups in monocots [21]. In wheat, 48 OPR genes were classified into five groups: there were six in Group I, four in Group II, 33 in Group III, three in Group IV, and two in Group V [20]. The OPR genes expression levels were different in different tissues of plants or under various biotic and abiotic stresses, based on their distinct biological functions. In maize, eight OPR genes were identified. ZmOPR1 and $Z m O P R 2$ were transiently induced by SA, chitooligosaccharides, and by infection with pathogens, but not by wounding. However, ZmOPR6, ZmOPR7, and ZmOPR8 were highly induced by wounding or JA, not involved in response to pathogens infection and SA [16]. In wheat, transgenic plants of TaOPR1 could improve the tolerance to salinity in an ABA-dependent manner [22]; the expression of TaOPR2 can be induced by wounding, drought, MeJA, Puccinia striiformis $f$. sp. Tritici, and Puccinia recondite f. sp. Tritici [23]. Overexpression of AtOPR3 in hexaploid wheat could enhance the wheat freezing tolerance [24]. Under the drought stress in rice, OsOPR7 expression level was upregulated to a peak within $0.5 \mathrm{~h}$ [25]. In Solanum lycopersicum, the SiOPR3 plants in which the SlOPR3 was knocked down accumulated less OPDA and JA-lle under Botrytis cinerea infection than the control and had increased susceptibility to B. cinereal [26]. In upland cotton (Gossypium hirsutum), the function of GhOPR3, which was 76\% homologous with the amino acid sequence of AtOPR3, has been well characterized. GhOPR3 can be phosphorylated by GhCPK33 at threonine-246 in peroxisomes. Thereby, the protein of GhOPR3 was decreased, which consequently suppressed JA biosynthesis and reduced the resistance of cotton to V. dahliae [27].

Cotton is an important economic and natural fiber crop worldwide. Its growth and yield are restricted by various biotic and abiotic stresses in the field. Verticillium wilt, which is caused by the soilborne fungus $V$. dahliae, is a devastating vascular disease in cotton. There are no upland cotton cultivars displaying high resistance to $V$. dahliae [28]. Nevertheless, the genome-wide identification of OPR genes in Gossypium has not been explicitly studied. In this study, OPRs genes were identified by the method of genome-wide analysis in Gossypium. Then, the putative 10 OPR genes of G. hirsutum, nine OPR genes of G. barbadense, five OPR genes of Gossypium arboreum, and three OPR genes of Gossypium raimondii were used to construct the gene phylogenetic tree. Ten GhOPRs and nine GbOPRs were analyzed, and gene structure, protein conserved motif, chromosome localization, and cis-acting regulatory elements were predicted in G. hirsutum. The results indicated that the OPR genes have potential functional and they were evolutionary in cotton. Subsequently, expression levels of GhOPRs under PEG6000 (two tissues and four time points), $\mathrm{NaCl}$ (two tissues and four time points), and V. dahliae (three tissues and eight time points) stresses were determined using RT-qPCR to better understand the OPR functions in stress responses. Silencing GhOPR9 in G. hirsutum can compromise cotton resistance to $V$. dahliae. Furthermore, we also found that GhOPR9 can modulate the expression levels of JA 
biosynthesis genes under $V$. dahliae infection. These results could contribute to screening more potential functional genes in order to improve resistance against biotic and abiotic stresses in cotton.

\section{Materials and Methods}

\subsection{Identification of OPR Family Genes in Cotton}

Proteomes and gene annotation data of G. hirsutum and G. barbadense are available from the newly assembled genome [29]. To identify OPR genes in cotton, the Hidden Markov Model (HMM) models of Oxidored_FMN (PF00724) were download from the Pfam database (http://pfam.xfam.org/) [30] and were used as query to conduct a homologous search (E-value $<1$ ) against proteomes of G. hirsutum and G. barbadense by HMMER v.3.1b2 software [31], respectively. Besides, protein sequences of A. thaliana OPRs were retrieved from The Arabidopsis Information Resource (TAIR) database (https: //www.arabidopsis.org/) and served as queries to perform similarity search (E-value $<1 \times 10^{-5}$, identity $>50 \%$ ) against G. hirsutum and G. barbadense proteomes using BLAST + v.2.6.0, respectively [32]. The sum total of object items in HMMER and BLAST search results were subjected to further filtering by InterProScan v.5.32-71.0. Items [33] containing the characteristic Oxidored_FMN (PF00724/IPR001155) domain were identified as OPRs. Besides, OPR genes from Gossypium arboreum, Gossypium raimondii, Helianthus annuus, Oryza sativa, Solanum lycopersicum, Triticum aestivum, Zea mays, and Arabidopsis thaliana were identified by the same method.

\subsection{Phylogenetic Analysis}

Amino acid sequences of OPRs identified in G. hirsutum, G. barbadense, and OPR genes from other plant species were subjected to multiple sequence alignment using MUSCLE [34]. After conducting a model test, a maximum likelihood (ML) phylogenic tree was constructed with the best substitution model using MEGA X software [35].

\subsection{Gene Structure Analysis and Conserved Motif Identification}

Exon-intron structure information of OPR genes and coordinates of characteristic domain were extracted from reference gene annotation data and InterProscan annotation results. Gene Structure Display Server (GSDS) v2.0 [36] was used to display gene structure and indicate characteristic domain coding regions. Conserved motifs were identified using the Multiple Expectation Maximization for Motif Elicitation (MEME) program v.5.0.5 [37] with the default parameters.

\subsection{Genomic Distribution, Collinearity and Duplication Analysis of Cotton OPR Genes}

The genomic coordinates of cotton $O P R$ genes were extracted from genome annotation data, and RIdeogram [38] was used to display genomic distribution of cotton OPR genes. MCScanX [39] was used to identify genomic collinear blocks and tandem duplications with the default parameters, and collinearity relationship was visualized by Circos v.0.69 [40].

\subsection{Promoter and Regulatory Analysis of Cotton OPR Genes}

The upstream $1.5 \mathrm{~kb}$ sequences of gene coding region of $O P R$ genes were extracted as promoter regions. Promoter region sequences were submitted to the PlantCARE database (http://bioinformatics. psb.ugent.be/webtools/plantcare/html/) to conduct the prediction of cis-acting elements. The cis-acting elements distribution upon promoters of OPR genes were displayed by GSDS v2.0 (http://gsds.cbi.pku. edu.cn./) [36].

\subsection{Plant Materials}

The resistant G. hirsutum cv. Zhongzhimian No. 2 to $V$. dahliae and the susceptible G. hirsutum cv. Jimian No.11 were the plant materials. Plants were grown in a growth chamber with $16 \mathrm{~h}$ day/8 h day/night cycle at $25^{\circ} \mathrm{C}$. 


\subsection{Treatment with PEG6000, $\mathrm{NaCl}$ and $\mathrm{V}$. dahliae}

Seedlings of G. hirsutum cv. Zhongzhimian No. 2 were used for gene expression in response to different stresses. For the abiotic stresses (drought and salt), three-leaf-stage seedlings were cultivated in a Hoagland liquid medium including $20 \%$ PEG6000 and $200 \mathrm{mM} \mathrm{NaCl}$, respectively. The leaves of cotton were collected at four time points $(0,3,6$, and $12 \mathrm{~h})$ for RNA extraction. $V$. dahliae infection was performed as described previously [41]. The seedling leaves, stems, and roots were harvested at eight time points $(0,1,3,6,9,12,24$, and $48 \mathrm{~h})$ after Vd080 infection for RNA extraction, respectively. At least 50 plants were treated by each experiment. Each time point samples contained three plants, the samples were quickly frozen in liquid nitrogen and stored at $-80^{\circ} \mathrm{C}$. The experiment was replicated twice.

\subsection{VIGS}

The technology of virus-induced gene silencing was performed as reported previously [42]. Fragments of GhOPR9 and GhPDS for evaluating VIGS marker gene were amplified from G. hirsutum cv. Zhongzhimian No.2 cDNA by PCR, and then integrated into the tobacco rattle virus (TRV) vector pYL156 at the XbaI-SacI sites using the In-Fusion HD Cloning Kit (Clontech, Mountainv View, CA, USA) according to the manufacturer's protocol. Then, the plasmids of pYL-GhOPR9, pYL-GhPDS, the pYL156 empty vector, and the auxiliary vector pLY192 were transformed into Agrobacterium tumefaciens strains GV3101. A positive A. tumefaciens single colony of each vector was cultured with $50 \mu \mathrm{g} / \mathrm{mL}$ kanamycin and $50 \mu \mathrm{g} / \mathrm{mL}$ rifampicin in LB medium at $28^{\circ} \mathrm{C}$ for $12-16 \mathrm{~h}$. The Agrobacterium cells were collected by centrifugation. Following, they were resuspended to a $\sim 1.0$ value of $\mathrm{OD}_{600}$ via using MMA solution (10 mM N-morpholino ethanesulfonic acid, $10 \mathrm{mM} \mathrm{MgCl}$ and $200 \mathrm{mM}$ acetosyringone). The Agrobacterium cells of pYL-GhOPR9 (TRV:GhOPR9), pYL-GhPDS (TRV:PDS), and pYL156 empty vector (TRV:00) were mixed with the Agrobacterium strains of pLY192 in a 1:1 ratio, respectively; they were incubated at $28^{\circ} \mathrm{C}$ for $3 \mathrm{~h}$ in the dark. Finally, the mixture cells of TRV:PDS, TRV:00, and TRV:GhOPR9 were infected into the cotyledons of which were fully expanded seedlings via needleless syringe. At least 50 plants were injected by each construct. Three plants were collected from each treatment at each time point. The experiment was replicated twice. When the newly true leaves of TRV:PDS lines presented a photobleaching phenotype, the silencing efficiency of the target gene GhOPR9 in TRV:GhOPR9 lines was examined using the newly true leaves via RT-qPCR, the TRV:00 lines were the control. The successfully silenced plants were used to inoculate with $V$. dahliae strain Vd080. The TRV:00 lines with Vd080 inoculation were the control.

\subsection{Pathogen Infection and Disease Assay}

The highly aggressive defoliating Vd080 was cultured as described previously [43]. The fungus was grown on potato dextrose agar medium at $25^{\circ} \mathrm{C}$ for seven days in a dark place. Then, the highly activated hyphae were collected and cultured in potato dextrose broth medium at $25^{\circ} \mathrm{C}$ for five days in dark place. The conidia of $V$. dahliae were resuspended in distilled water. The final concentration of $10^{7}$ spore $\mathrm{mL}^{-1}$ was used for infection. Fungal inoculation was conducted as described previously [41]. The wild type (WT) cotton seedlings were infected by Vd080 to make sure that the species can be infected with Vd080 and present the typical symptom of $V$. dahliae, and the WT seedlings infected with water were the control. The plants roots were dipped into $1 \times 10^{7}$ spore $\mathrm{mL}^{-1}$ conidial suspension for $10 \mathrm{~min}$. The successful silencing plants of TRV:GhOPR9 were infected with conidial suspension. After inoculation, cotton leaves and roots were collected at four time points (00, 01, 12, and $24 \mathrm{~h}$ ) and washed with water for RNA extraction to detect the expression levels of resistance genes in JA pathway. A disease index (DI) was calculated as described previously [44]. Seedling stems were cut from each line at the same position to investigate the vascular wilt symptom via a microscope. The fungal DNA abundance assay was performed as described previously [27]. Seedling stems were collected at three weeks post-inoculation. Total DNA was extracted for qPCR to detect the fungal biomass. The ITS1-F/ST-VE1-R primer were used to detect the fungal DNA. The TRV:00 lines with 
Vd080 inoculation were the control. The cotton gene GhUB7 was used as control for qPCR analysis. Each experiment was replicated twice. The primers used in this study are listed in Supplemental Table S1.

\subsection{Callose Deposition}

Callose depositions were visualized by aniline blue staining as described previously [45]. Leaf sample were first destained in 3:1 ethanol/acetic acid for $3 \mathrm{~h}$ and were then soaked into $70 \%$ and 50\% ethanol for $2 \mathrm{~h}$, respectively. Following, leaves were transferred into the water for $12 \mathrm{~h}$. And then, the leaves were destained in $10 \%(\mathrm{w} / \mathrm{v}) \mathrm{NaOH}$ for $2 \mathrm{~h}$. Finally, they were stained with $0.01 \%(\mathrm{w} / \mathrm{v})$ aniline blue in $150 \mathrm{mM} \mathrm{K}_{2} \mathrm{POH}_{4}$ (pH9.5). Stained leaves were imaged on fluorescence microscopy. At least three leaves of TRV:00 and TRV:GhOPR9 lines at three weeks post-inoculation were observed, and each experiments were replicated twice.

\subsection{RNA/DNA Extracted and Real-time Quantitative PCR/Quantitative PCR Analysis}

Total RNA was extracted from the collected samples using the RNAprep Pure Plant Plus Kit (Polysaccharides \& Polyphenolics-rich) (TransGen Biotech, Beijing, China) according to the manufacturer's instructions. The first cDNA strand was synthesized by using the All-in-One First-Strand cDNA Synthesis Super Mix for qPCR Kit (One-Step gDNA Removal) (TransGen, Beijing, China) according to the manufacturer's instructions. The RT-qPCR was performed using the Roche Light Cycler 480 System (Roche, Mannheim, Germany). A 20- $\mu$ L reaction system was used, the components of reaction were displayed as follow: $2 \mu \mathrm{L}(200 \mathrm{ng})$ of cDNA, $0.4 \mu \mathrm{L}$ of forward primer $(10.0 \mu \mathrm{mol} / \mathrm{L})$, $0.4 \mu \mathrm{L}$ of reverse primer $(10.0 \mu \mathrm{mol} / \mathrm{L}), 10 \mu \mathrm{L}$ of $2 \times$ TransStart Top/Tip Green qPCR Super Mix, and $7.2 \mu \mathrm{L}$ of nuclease-free water. The reaction procedure was completed as the following program: $94{ }^{\circ} \mathrm{C}$ for $30 \mathrm{~s} ; 45$ cycles of $94{ }^{\circ} \mathrm{C}$ for $5 \mathrm{~s}, 60^{\circ} \mathrm{C}$ for $15 \mathrm{~s}, 72{ }^{\circ} \mathrm{C}$ for $10 \mathrm{~s}$; and $4{ }^{\circ} \mathrm{C}$ for ending. Total DNA was extracted from the collected samples using the Fungal DNA Kit (Omega Bio-tek, Norcross Georgia, US according to the manufacturer's instructions. The qPCR of DNA samples was performed as above describe. Primer sequences used in the present study are presented in Supplemental Table S1. The expression levels of OPR genes were analyzed by the $2^{-\triangle \Delta C T}$ method.

\section{Results}

\subsection{Genome-Wide Identification of OPR Genes Family in Cotton}

We identified 10, 9, 5, and 3 OPRs by detecting the Oxidored_FMN (ID:PF00724) conserved domain via Pfam in G. hirsutum (ZJU), G. barbadense (ZJU), G. arboreum, and G. raimondii, respectively. The gene ID, genomic location, DNA length, coding sequence length, protein length, molecular weight (MW), and isoelectric point (IP) are presented in Supplemental Table S2. The lengths of OPR proteins ranged from 156 to 418 amino acids, the MW ranged from $17.476 \mathrm{kDa}$ to $46.634 \mathrm{kDa}$, and the IP ranged from 4.914 to 8.749 .

\subsection{Phylogenetic Analysis of OPR Genes}

To further investigate the phylogenetic relationships of the OPRs in different species, we used the 10 OPRs from G. hirsutum, nine OPRs from G. barbadense, five OPRs from G. arboreum, three OPRs from G. raimondii, 22 OPRs from Helianthus annuus, four OPRs from S. lycopersicum, three OPRs from $A$. thaliana, 48 OPRs from T. aestivum, 12 OPRs from O. sativa, and eight OPRs from Z. mays for constructing a phylogenetic tree by MEGA X software using the ML method. The phylogenetic tree divided 124 OPRs into five different groups (Figure 1). The different species OPRs named were displayed in Supplemental Table S3.

The result showed that Group I was the biggest, which had 54 OPR proteins. Group V was the smallest, which gathered only 11 OPRs. Group II, Group III, and Group IV contained 21, 16, and 22 OPR proteins, respectively. Monocots species OPR members were clustered in all five Groups, such as 
TaOPRs, which was consistent with previous studies [20]. Dicots species OPRs were distributed in Group I and Group II. Interestingly, most of dicots OPRs were tightly related to AtOPR1 and AtOPR2 and were gathered in Group I, contain $20 \mathrm{HaOPRs}, 17$ OPRs from four different species cotton and three SlOPRs. Group IV contain 10 OPR members of cotton, two HaOPRs, and one SlOPR and tightly linked to AtOPR3. Compared to other species, cotton OPRs have a closer relationship with the AtOPRs. GaOPR4, GbOPR4, GbOPR7, GbOPR8, GhOPR4, GhOPR7, GhOPR8, and GhOPR9 were clustered in the same clad with AtOPR1 and AtOPR2. GaOPR5, GbOPR3, GbOPR6, GbOPR9, GhOPR3, GhOPR6, GhOPR10, and GrOPR3II showed a closely relationship with the AtOPR3. A previous study showed that OPR3 plays a key role in JA biosynthesis in A. thaliana [14]. The functions of OPRs that are tightly related to AtOPR1 and AtOPR2 in other species are still not well understood. Their contributions could not be ignored. Therefore, there were difference in the functions of the OPR genes between monocotyledons and dicotyledons. Furthermore, the protein of OPRs had the conserved domains, but their functions might be diverse.

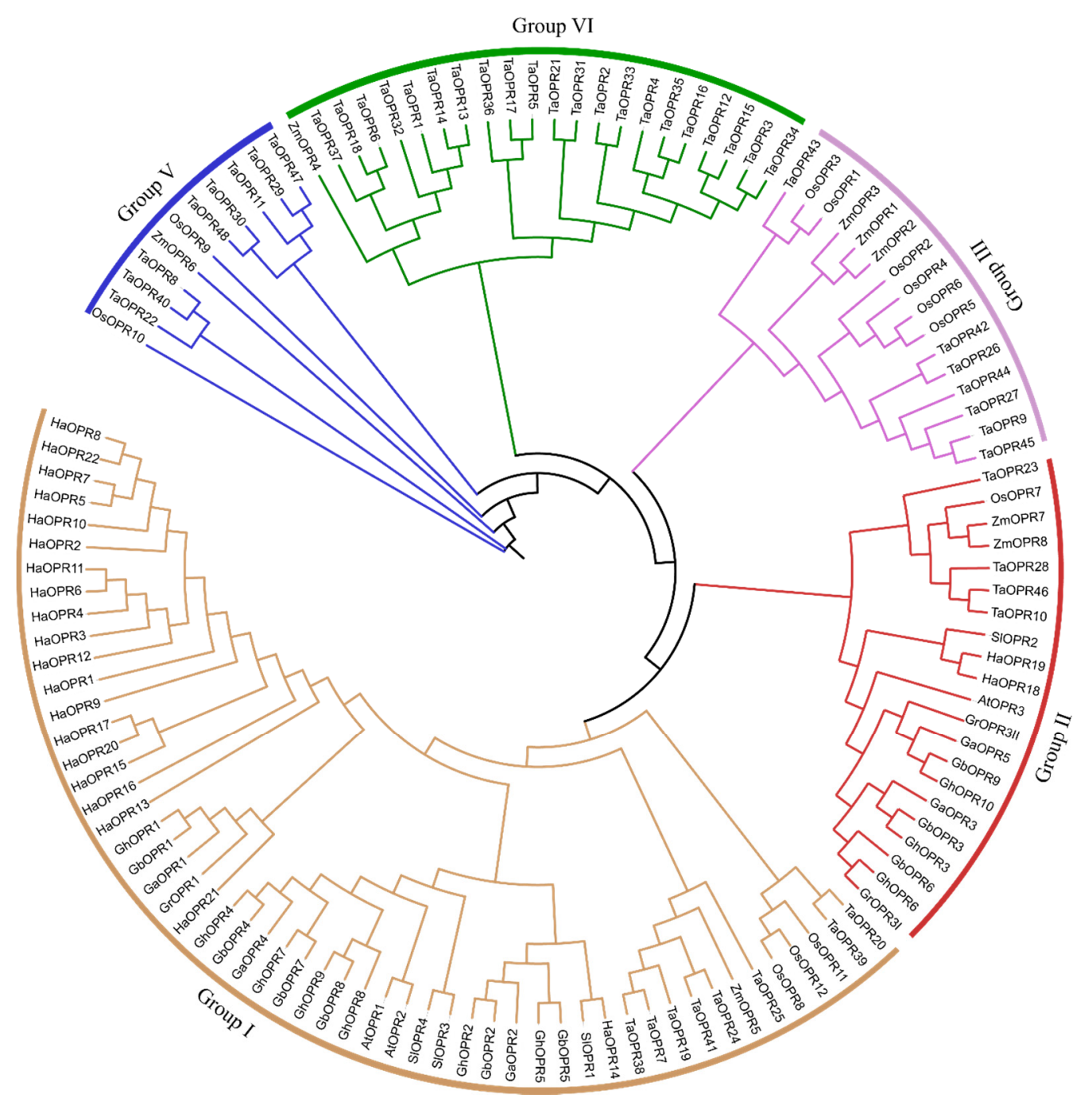

Figure 1. The maximum likelihood (ML) phylogenetic tree of the 12-oxo-phytodienoic acid reductase $(O P R)$ family. The tree was drawn with the full-length amino acid sequences of OPR genes from Arabidopsis thaliana (Linn.) Heynh. (At), Gossypium arboreum L. (Ga), G. barbadense L. (Gb), G. hirsutum L. (Gh), G. raimondii Ulbr. (Gr), Helianthus annuus L. (Ha), Oryza sativa L. (Os), Solanum lycopersicum L. (Sl), Triticum aestivum L. (Ta), and Zea mays L. (Zm), using MEGA X, with 1000 replicates. They were classified into five groups. Group I, Group II, Group III, Group VI, and Group V are represented by orange, red, purple, green, and blue, respectively. 


\subsection{Gene Structural, Conserved Motif Analysis of OPRs in Gossypium}

To better understand the phylogenetic relationships and gene structures of the $O P R$ family in cotton, we used the 10 OPRs and nine OPRs from G. hirsutum and G. barbadense, respectively, and three OPRs from $A$. thaliana for constructing a phylogenetic tree by MEGA X software (Figure 2a). The result showed that the relationships of the OPRs were consist with the phylogenetic tree in Figure 1. The OPR proteins from cotton were divided into three subgroups. GbOPR4, GbOPR7, GbOPR8, GhOPR4, GhOPR7, GhOPR8, and GhOPR9 were gathered in the same clad with AtOPR1 and AtOPR2. GbOPR3, GbOPR6, GbOPR9, GhOPR3, GhOPR6, and GhOPR10 were clustered in a same clad with the AtOPR3. Meanwhile, GbOPR1, GbOPR2, GbOPR5, GhOPR1, GhOPR2, and GhOPR5 were grouped into another clade.
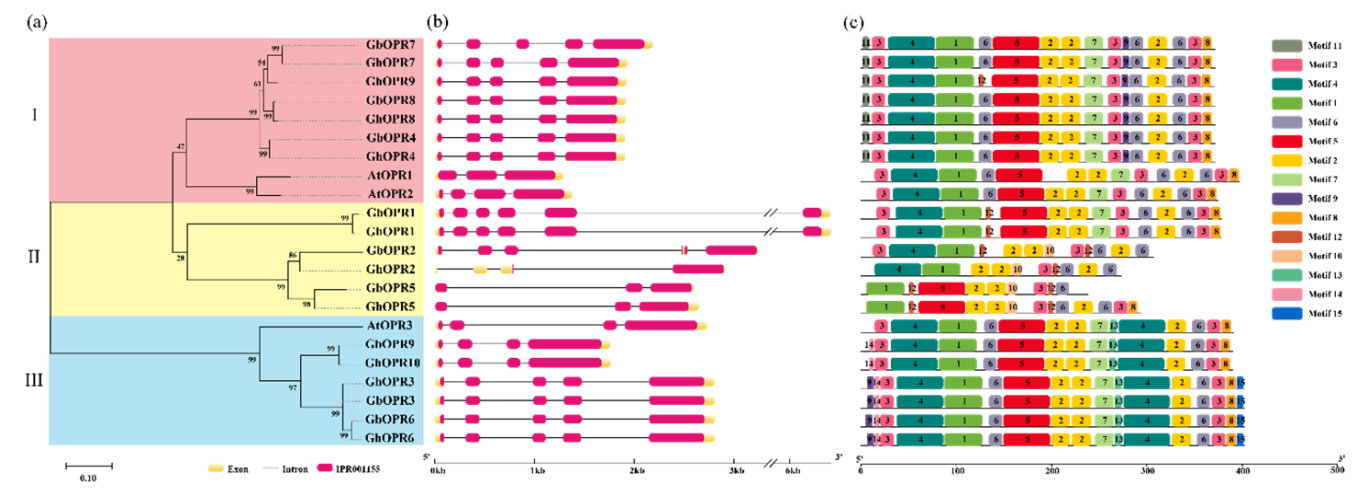

Figure 2. Structural and motif analysis of two allotetraploid cotton OPR genes. (a) Phylogenetic tree of OPR genes in G. barbadense and G. hirsutum. The ML phylogenetic tree was constructed by using MEGA $X$ with 1000 replicates. (b) Exon-intron structures of GhOPR and GbOPR genes. Orange boxes mean exons, and black lines mean introns, and red color represent conserved domain. (c) Conserved motifs of GhOPR and GbOPR proteins. Fifteen conserved motifs are represented by different color boxes.

We analyzed the exon-intron structures of OPR genes. 12 OPRs in cotton contained five exons and four introns. Three OPR genes contained four exons and three introns: GhOPR2, GbOPR9 and GhOPR10. Two OPR genes possessed three exons and two introns: GbOPR5 and GhOPR5. GbOPR1 and GhOPR1 have the most exons and introns-six and five, respectively. As presented in Figure 2b, the intron or exon numbers and lengths in different subgroups were different. Loss or gain of the exon/intron took place during the evolution of $O P R$ genes family in cotton, especially in sub. II. Our results suggested that $O P R$ genes maintained a relatively constant exon-intron composition during evolution of the Gossypium genome.

To estimate the conserved motif of OPR proteins in Gossypium, MEME analysis was performed to predict distinct motifs. Fifteen putative motifs named motifs 1-15, were finally identified. These motifs contained varied from 6 to 50 amino acids, and the details of the 15 conserved motifs are displayed in Supplemental Table S4. As shown in Figure 2c, most of the orthologous proteins shared similar motif members in the same subgroup. In subgroup I, there have motif $1-9$ and motif 11 in each OPR. Compared to other proteases, GhOPR9 lacked one motif 6 , instead of a motif 12 . In sub. II, the motifs displayed different patterns, GbOPR1 and GhOPR1 had the same motifs 1-8, 12; GbOPR2 and GhOPR2 lacked motifs 5 and 7, but gain a motif 10; GbOPR5 and GhOPR5 lacked motif 4 and motif 7, also have motif 10. In sub. II, OPRs shared motif 1-9 and 13-15 in relatively conserved pattern. In addition, each class have the specific motifs, such as motif 11 in sub. I, motif 12 in sub. II, motif 13-15 in sub. III. Among of the motifs, motif 1 , motif 2 , motif 3 , motif 4 , motif 5 , and motif 6 were corresponded to the beta/alpha barrel which might be related to the protein secondary structures [20]. In conclusion, the results provided an additional evidence to support the classification results. 


\subsection{Chromosomal Location and Gene Synteny Analysis of OPR Genes in Gossypium}

The distribution of OPR genes was investigated by positioning their approximate positions on cotton chromosome. As shown in Supplemental Figure S1, chromosomes GH_A01, GH_A05, GH_D01, GH_D05, and GH_D06 contained all of the GhOPR genes; and chromosomes GB_A01, GB_A05, GB_D01, GB_D05, and GB_D06 contained all of the GbOPR genes. In G. hirsutum, chromosome GH_D05 have the most GhOPR genes (four, 40\%). Moreover, two OPR genes were distributed in chromosomes GH_A01 and GH_A05 and only one gene in chromosomes GH_D01 and GH_D06. Furthermore, the genes in chromosome GH_A05 and GH_D05 were primarily anchored on chromosome head. In G. barbadense, the distribution of OPR genes was almost the same as the G. hirsutum. However, compared to GH_D05, GB_D05 lacked one OPR gene.

To further understand the relationships of OPR genes between G. hirsutum and G. barbadense, syntenic analysis were performed (Figure 3). Among the candidate OPR genes, eight GhOPRs were the orthologous genes of the eight GbOPRs. Some OPRs of G. hirsutum had not only one orthologous gene in G. barbadense, such as GhOPR2 and GhOPR5, which had two genes (GbOPR2 and GbOPR5); GhOPR3, GhOPR6, and GhOPR10 had three genes (GbOPR3, GbOPR6, and GbOPR9); and GhOPR4 and GhOPR7 had two genes (GbOPR4 and GbOPR7). In addition, there were three paralogous gene pairs (GhOPR2/5, GhOPR3/6/10 and GhOPR4/7) in G. hirsutum genome, and three paralogous gene pairs (GbOPR2/5, GbOPR3/6/9 and GbOPR4/7) in G. barbadense genome (Supplemental Table S5). Furthermore, seven GhOPRs and seven GbOPRs were classified into WGD or segmental duplications (Supplemental Table S5), and one OPR member was classified into dispersed duplication in G. hirsutum and G. barbadense, respectively. It was noteworthy that two OPRs were tandem duplication genes in G. hirsutum. WGD or segmental duplication might play a crucial role in the expansion of the OPR gene family.

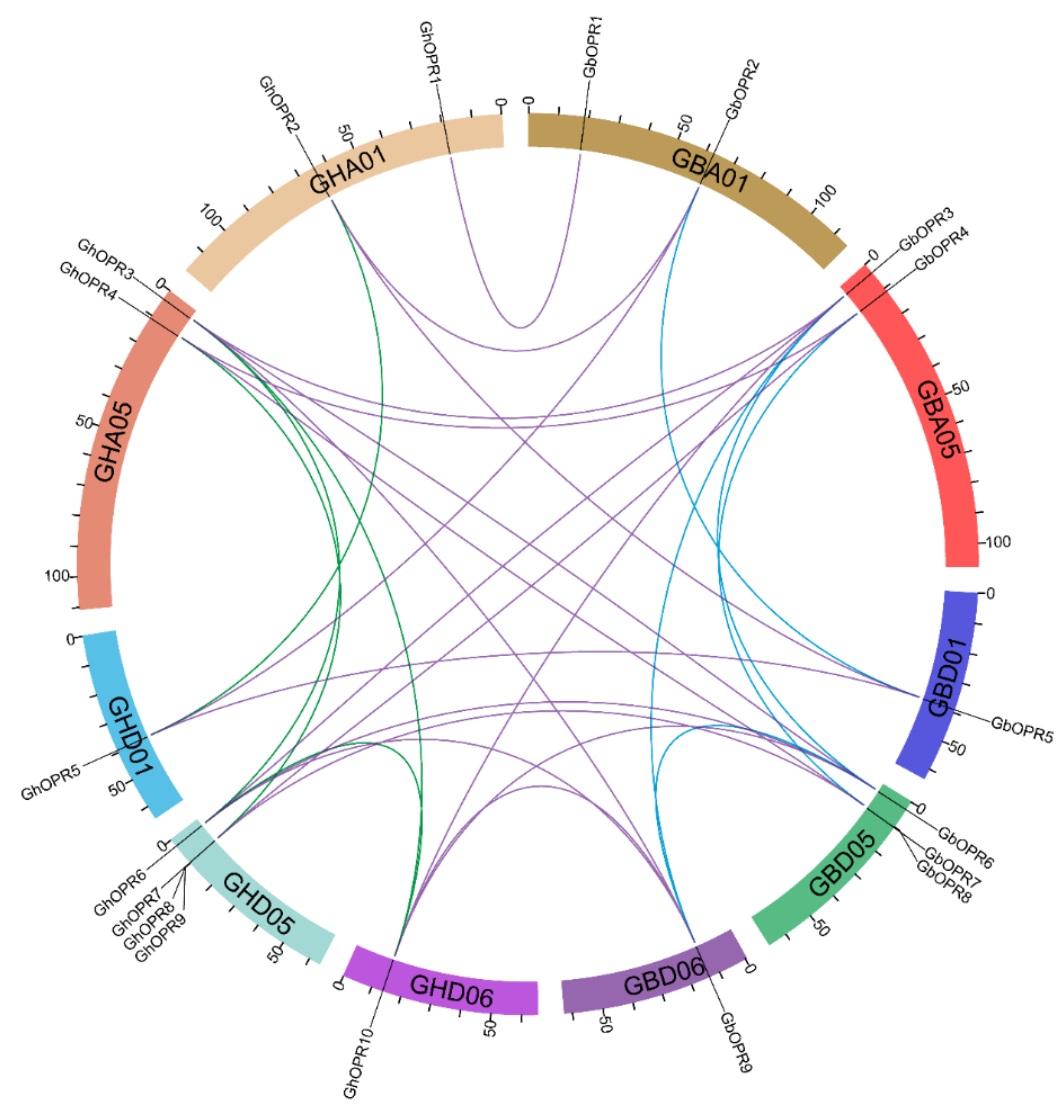

Figure 3. The synteny relationship of $O P R$ genes between G. hirsutum and G. barbadense. Five upland cotton and five sea-island cotton chromosomes are displayed with different random colors. Lines in purple represent orthologous gene pairs, green represent upland cotton paralogous gene pairs, and blue represent sea-island paralogous gene pairs. 


\subsection{Prediction of Cis-Acting Elements in the Promoters of OPRs in G. hirsutum}

To further predict the possible biological functions of GhOPRs, the $1.5 \mathrm{~kb}$ upstream promoter regions of all GhOPRs were obtained and analyzed the cis-acting regulatory elements via the online database PlantCARE. Thirty kinds of elements were discovered in the promoter regions of OPR genes in G. hirsutum (Supplemental Table S6). The cis-acting elements which were the binding regions of transcription factors played a crucial role in regulating gene expression. As shown in Table S6, a large number of cis-acting elements were predicted to be related to transcription, various hormones and stresses response, cell cycle, and development. Four kinds of elements that related to the core cis-acting element, light response, and wounding response were predicted in all GhOPR genes promoter regions. The number of the core cis-acting elements was 682 in G. hirsutum, which was the most cis-acting element. In particular, a specific element might be related to binding site, MYBHv1 binding site was found in GhOPR10 promoter region, a cis-acting element predicted to be related to circadian was just only discovered in promoter region of GhOPR6. The cis-acting elements might be related to hormone signaling pathways and response to various stresses were predicted in GhOPRs promoter regions, for instance ABA, auxin (IAA), ET, gibberellins (GA), JA, methyl jasmonate (MeJA), SA, cold, drought, wounding, pathogen, etc. Interestingly, a JA response cis-acting element was just found in GhOPR9 promoter region (Table 1), indicating that GhOPR9 might participate in JA-mediated signaling pathways. These results indicated that OPR genes in G. hirsutum might perform different biological functions.

\subsection{Expression Patterns of GhOPRs in Response to Abiotic Stresses}

To further understand expression levels of the GhOPRs under drought and salt stresses, RT-qPCR was performed using the leaves of upland cotton Zhongzhimian No. 2 treated with PEG6000 and $\mathrm{NaCl}$ (Figure 4). The results showed that all of GhOPRs were repressed by PEG6000 and induced by $\mathrm{NaCl}$, respectively. Under the PEG stress, the transcription levels of GhOPRs exhibited a decreasing trend over 00-12 $\mathrm{h}$ ranges in leaves, except for GhOPR7. In subgroup I and subgroup III, GhOPR genes expressions were down-regulated at $06 \mathrm{~h}$, and then, up-regulated at $12 \mathrm{~h}$, but were still lower than $00 \mathrm{~h}$. Under $\mathrm{NaCl}$ treatment, all of GhOPRs expression levels were significantly increased. Eight of these GhOPRs reached peak transcription levels at $06 \mathrm{~h}$, and then, decreased at $12 \mathrm{~h}$, but still were higher than control. In addition, GhOPR3, GhOPR6, and GhOPR10 got the peak expression levels at $12 \mathrm{~h}$. Furthermore, paralogous genes had the same transcription patterns in response to PEG or $\mathrm{NaCl}$ treatment, such as GhOPR2/5 and GhOPR4/7. These results suggested that the GhOPRs might play an important role in response to abiotic stresses in cotton.

\subsection{Expression Patterns of OPR Genes in G. hirsutum Under V. dahliae Inoculation}

To further ascertain whether GhOPRs RNA levels were related to $V$. dahliae infection, we performed RT-qPCR to analyse the expression profiles of OPR genes using leaf, stem and root of Zhongzhimian No. 2 under $V$. dahliae inoculation during $48 \mathrm{~h}$. The relative expression of GhOPRs showed various expression profiles (Figure 5). 
Table 1. Prediction of cis-acting regulatory elements about various responses of GhOPR genes.

\begin{tabular}{|c|c|c|c|c|c|c|c|c|c|c|}
\hline Element of Response & GhOPR1 & GhOPR2 & GhOPR3 & GhOPR4 & GhOPR5 & GhOPR6 & GhOPR7 & GhOPR8 & GhOPR9 & GhOPR10 \\
\hline $\mathrm{ABA}$ & 3 & & 1 & & 1 & 1 & 1 & 2 & & \\
\hline anaerobic & & 1 & & & & 1 & & 1 & 1 & 3 \\
\hline auxin & & 1 & & 2 & 1 & & 1 & & 1 & \\
\hline cold & & 1 & 3 & & & 1 & & 3 & & \\
\hline defense and stress & 1 & & 1 & 1 & & 1 & & & & 2 \\
\hline dehydration & & & & 3 & 2 & 1 & 1 & 4 & 1 & 2 \\
\hline drought & & & & & 1 & & 1 & & 1 & 1 \\
\hline ETH & 5 & 1 & 2 & 5 & & 4 & 2 & 10 & 6 & \\
\hline GA & & 2 & 1 & & 11 & & 1 & & 2 & \\
\hline osmotic stress, nutrient starvation & 7 & 3 & 8 & 5 & & 8 & 3 & 3 & 4 & \\
\hline JA & & & & & & & & & 1 & \\
\hline light & 15 & 3 & 9 & 9 & 8 & 6 & 11 & 4 & 4 & 8 \\
\hline MeJA & & & & 6 & & 2 & 2 & 6 & 2 & \\
\hline SA & & 1 & & 1 & 5 & & 1 & & & \\
\hline stress & 1 & & & 1 & & & & & 1 & 1 \\
\hline wounding and pathogen & 2 & 3 & & 2 & 2 & & 1 & & 6 & 2 \\
\hline wounding & 15 & 25 & 19 & 21 & 16 & 17 & 23 & 10 & 22 & 27 \\
\hline
\end{tabular}

The prediction of cis-acting regulatory elements were identified via the online database PlantCARE by using the $1.5 \mathrm{~kb}$ upstream of the allotetraploid cotton G. hirsutum OPR genes. The table list the number of cis-acting elements to various responses. 
(a)

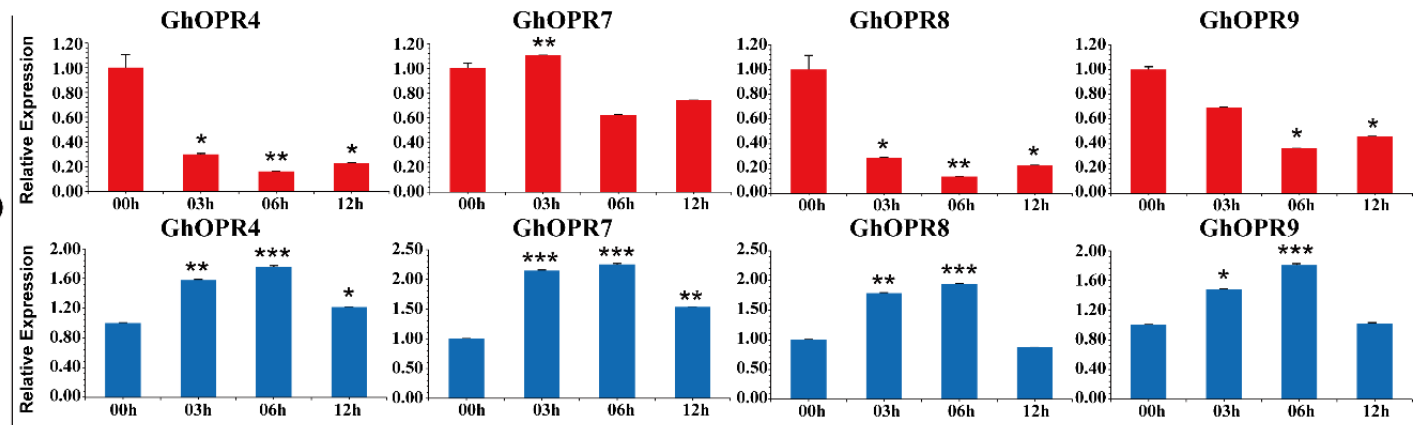

(b)

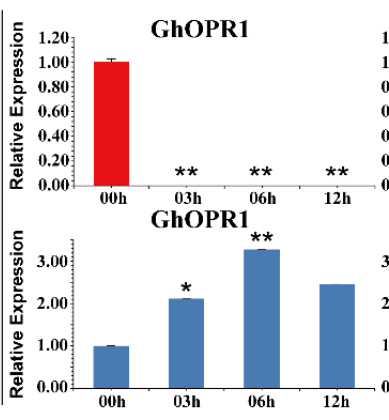

GhOPR2

GhOPR5

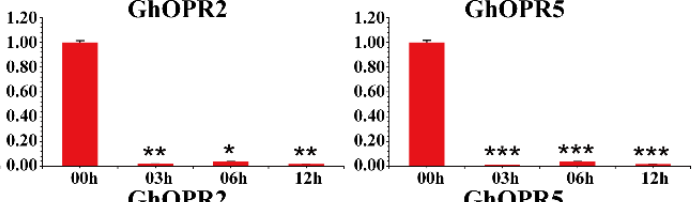

GhOPR2
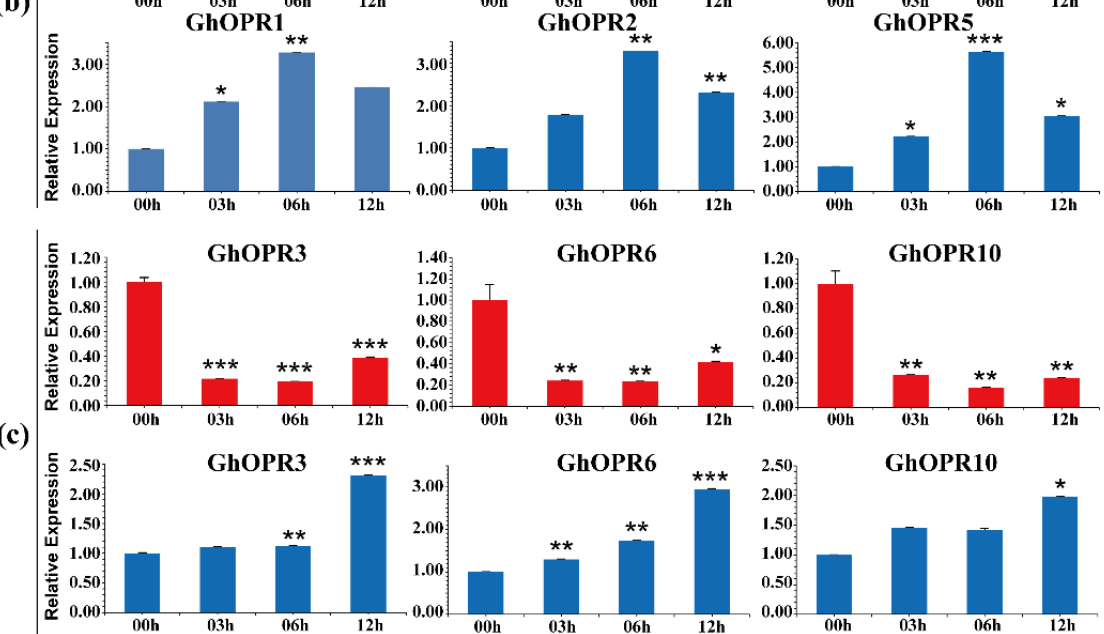

Figure 4. Analysis expression patterns of GhOPRs under abiotic stresses by Real-time quantitative PCR. (a) The expression levels of GhOPRs in subgroup I. (b) The expression levels of GhOPRs in subgroup II. (c) The expression levels of GhOPRs in subgroup III. The red columns represent the expression levels of GhOPRs under PEG6000 treatment; and blue columns represent the expression levels of GhOPRs under $\mathrm{NaCl}$ treatment. Values represent means \pm standard deviation of three replicates. Asterisks reveal the gene significantly higher or lower in $3 \mathrm{~h}, 6 \mathrm{~h}$, and $12 \mathrm{~h}$ than in $0 \mathrm{~h}$ by $t$-test ${ }^{*} p<0.05,{ }^{* *} p<0.01$, $* * * p<0.001)$.

In G. hirsutum, nine OPRs were decreased at $1 \mathrm{~h}$, followed by an increase in leaves, except GhOPR 1 (Figure 5a). In subgroup I and subgroup II, most expression levels of GhOPRs got the peak at the $12 \mathrm{~h}$ and then were downregulated. In subgroup III, GhOPR3, GhOPR6, and GhOPR10 were highly expressed. GhOPR3 and GhOPR 6 were up-regulated from $1 \mathrm{~h}$ to $6 \mathrm{~h}$ and down-regulated from $9 \mathrm{~h}$ to $24 \mathrm{~h}$ in leaves, and the highest expression levels were reached at $48 \mathrm{~h}$. All OPRs were significant induced in root (Figure 5b). In subgroup I and subgroup II, our results showed that the expression levels of GhOPR4, GhOPR7, GhOPR8, GhOPR9, GhOPR1, GhOPR2, and GhOPR5 were significantly increased in root. GhOPR5 got the highest expression level at $48 \mathrm{~h}$, and the other six GhOPRs gained their highest expression levels at $24 \mathrm{~h}$. The expression levels of GhOPR9, GhOPR1, GhOPR2 and GhOPR 5 were almost sustainably increased during the process under $V$. dahliae inoculation in root in $24 \mathrm{~h}$. In particular, GhOPR9 increased more than 100 times at $24 \mathrm{~h}$. But in sub. III, the genes were downregulated from 01 to $24 \mathrm{~h}$ after $V$. dahliae inoculation. All of OPRs received their highest expression levels at $12 \mathrm{~h}$ in stem (Figure 5c). The GhOPR9 was evidently upregulated by four times at $24 \mathrm{~h}$. The GhOPRs were significantly higher induced by $V$. dahliae in root than in leaf and stem. The GhOPRs expression patterns were similar in same subgroup in each tissue. These results suggested that the GhOPRs might be play an important role in response to $V$. dahliae infection in cotton. 


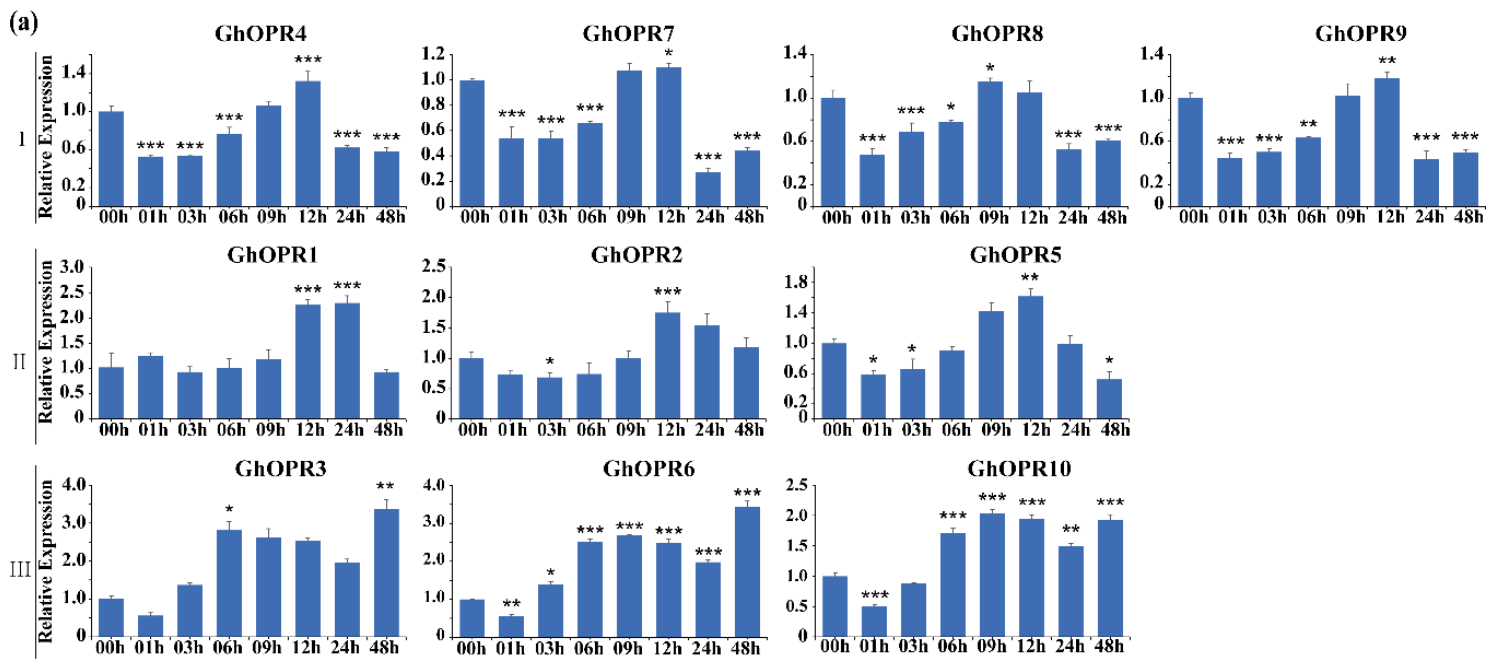

(b)

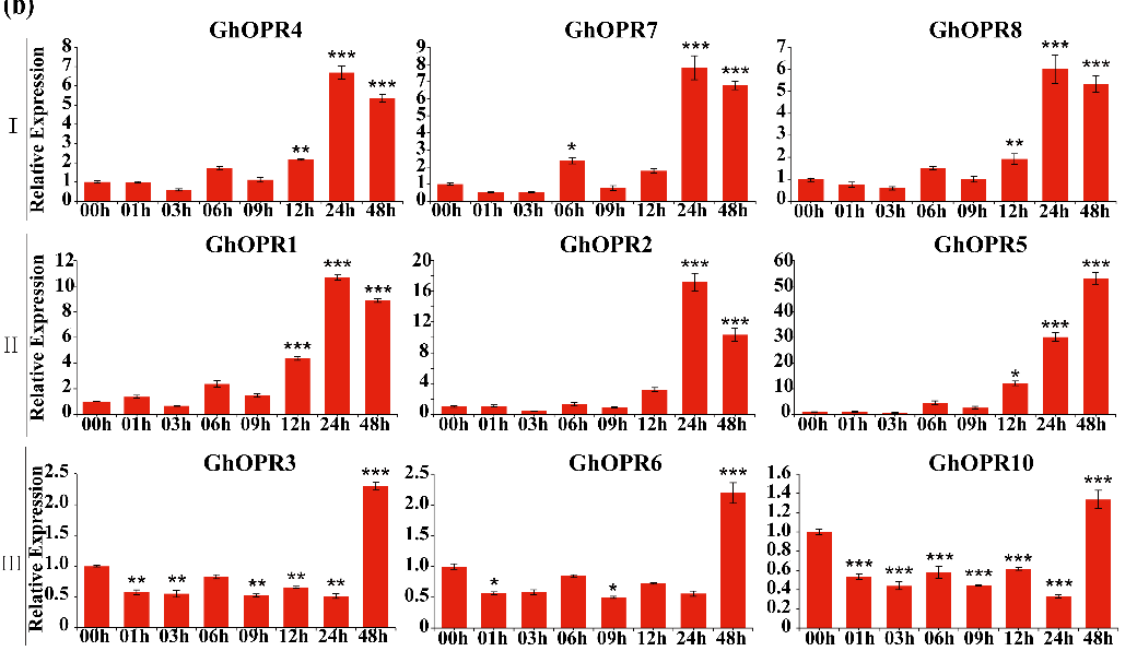

(c)
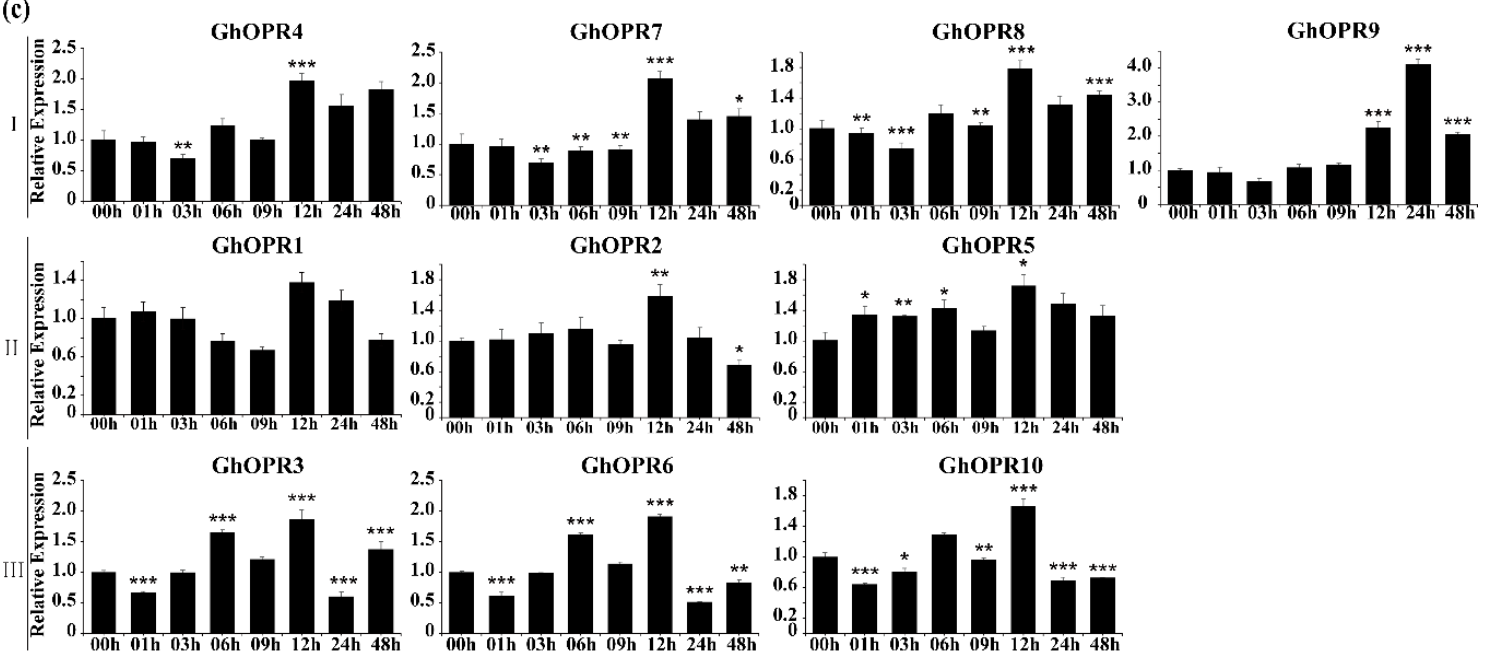

Figure 5. Analysis expression levels of GhOPRs under $V$. dahliae inoculation by RT-qPCR. The blue, red and black colors represent the sample of leaves, roots and stems, respectively. (a) The expression levels of GhOPRs under $V$. dahliae inoculation in leaf. (b) The expression levels of GhOPRs under $V$. dahliae inoculation in root. (c) The expression levels of GhOPRs under $V$. dahliae inoculation in stem. The samples were collected at $0,1,3,6,9,12,24$, and $48 \mathrm{~h}$ after Vd080 inoculation. Values represent means \pm standard deviation of three replicates. Asterisks reveal the gene significantly higher or lower in other time points than in $0 \mathrm{~h}$ by $t$-test $\left({ }^{*} p<0.05,{ }^{* *} p<0.01\right.$, $\left.{ }^{* * *} p<0.001\right)$. 


\subsection{Silencing GhOPR9 Attenuates the Resistance of Cotton to V. dahliae}

Expression profiles of GhOPRs showed that GhOPR9 was significantly induced in cotton under $V$. dahliae infection. To investigate the role of GhOPR9 in Verticillium wilt resistance, TRV-based VIGS was performed using resistant G. hirsutum cv. Zhongzhimian No.2. After cotton growing 10 days, the code sequences of GhOPR9 which about 250 bp were integrated into the vector pTRV2 (TRV:GhOPR9) for cotton seedlings infection. The fragment of GhPDS (TRV:GhPDS) or the pTRV2 empty vector (TRV:00) was performed as a VIGS indicator or a control to infection the plants cotyledon. When the newly true leaves that were infected with TRV:GhPDS showed a photobleaching phenotype (Figure 6a), the gene-silenced efficiency of TRV:00 and TRV:GhOPR9 plants was performed by RT-qPCR. RT-qPCR results showed that the gene silencing of GhOPR9 was successful (Figure 6b). Then, the gene-silenced plants were infected with Vd080 at the three leaf-stage. The TRV:00 plants were infected with Vd080 as control. The typical disease symptoms such as wilting, chlorosis, necrosis and darken vascular bundles was present on the WT cotton plants under Vd080 infection (Figure 6c,d). Compared to the TRV:00 plants, GhOPR9-silenced plants displayed more severely symptoms than the control (Figure 6c,e). The results displayed that GhOPR9-silenced plants significantly impaired the resistance to Vd080. The disease index analysis and fungal biomass detection of GhOPR9-silenced lines were much higher than the TRV:00 lines (Figure 6f,g). Moreover, GhOPR9-silenced lines displayed weakly callose deposition after infection with Vd080, compared to the TRV:00 plants (Figure 6h). These results suggested that silencing of GhOPR9 can increase the susceptibility of cotton to $V$. dahliae infection.

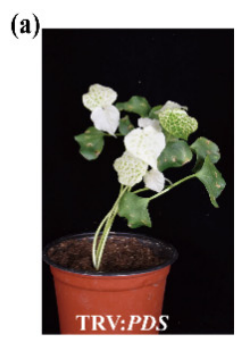

(b)

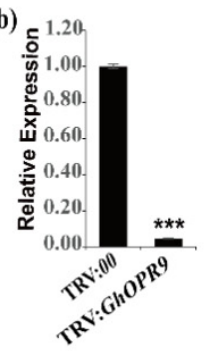

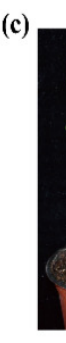

(d)

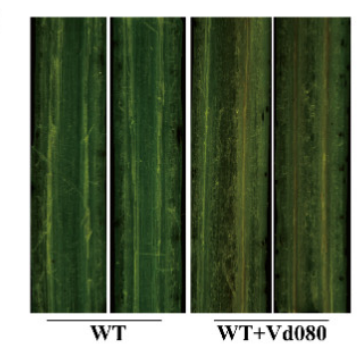

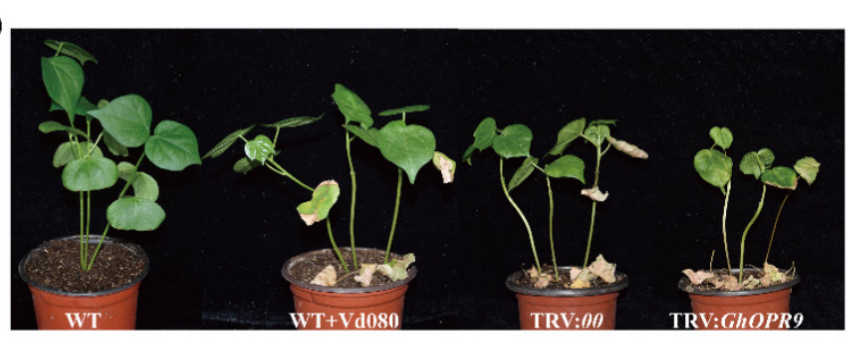

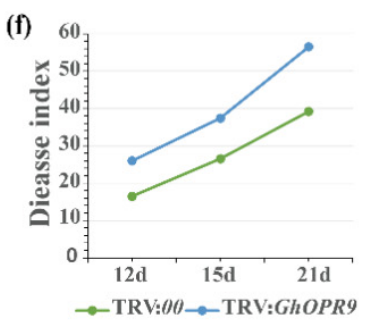

(e)

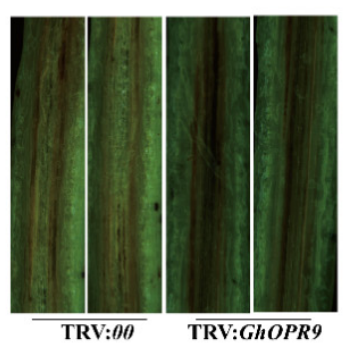

(g)

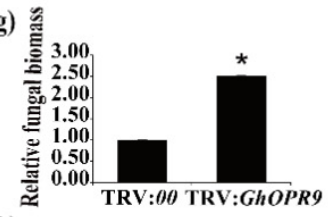

(h)

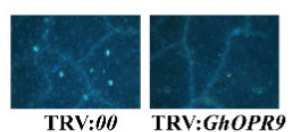

Figure 6. GhOPR9 positively regulates cotton resistance against $V$. dahliae in the resistant G. hirsutum cv. Zhongzhimian No.2. (a) TRV:PDS was used as the indicator to evaluate VIGS. (b) The expression level of GhOPR9 in the TRV:00 and TRV:GhOPR9 plants. Total RNA was isolated from roots at 10 days post-agroinfiltration. GhUB7 was used as the reference. Each experiment was performed using three independent replicates. (c) Disease symptoms of the cotton plants after Vd080 infection. Photographs were taken at 21 days after inoculation. (d) Disease symptoms in stems of the WT plants at 21 days after Vd080 inoculation. Vascular browning was appeared in WT + Vd080 plants. (e) Disease symptoms in stems of the TRV:00 and TRV:GhOPR9 plants. (f) Disease index of the TRV:00 and TRV:GhOPR9 plants at 12 days, 15 days, and 21 days after inoculation with Vd080. Each experiment was performed using three replicates. (g) qPCR analysis of the relative fungal biomass in stems of the TRV:00 and TRV:GhOPR9 plants at 21 days after Vd080 inoculation. Each experiment was performed using three replicates. Differences between groups were compared using the $t$-test ${ }^{*} p<0.05,{ }^{* * *} p<0.001$ ). (h) Callose deposition in leaves of the TRV:00 and TRV:GhOPR9 plants at 21 days after Vd080 inoculation. Leaves were imaged on fluorescence microscopy. 


\subsection{GhOPR9 Modulates Expression of JA-Regulated Defence Genes under V. dahliae Inoculation}

To test whether knock-down of the GhOPR9 gene impacted the expression of JA pathway-regulated genes under the $V$. dahliae infection or not, RT-qPCR were performed in the background of cotton Zhongzhimian No.2 in which GhOPR9 was silenced after $V$. dahliae inoculation, TRV:00 lines under the $V$. dahliae inoculation were the control. $L O X, A O S$ and $A O C$ are the upstream genes of OPR2 in JAs biosynthesis pathway [46]. The GhLOX2, GhLOX3, GhLOX4, GhLOX6, GhAOS, GhAOC, and the OPR3 of G. hirsutum were selected for the candidate genes. As Figure 7 shows, GhAOS and GhAOC transcriptional levels were increased the peak levels at $01 \mathrm{~h}$ but decreased at $12 \mathrm{~h}$ and $24 \mathrm{~h}$ in roots (Figure 7b). Compared to the TRV:00 lines, the expression levels of GhAOS and GhAOC were lower in the TRV:GhOPR9 plants at $1 \mathrm{~h}, 12 \mathrm{~h}$, and $24 \mathrm{~h}$. The expression level of GhLOX2 in TRV:GhOPR9 plants leaves was higher than TRV:00 lines at $01 \mathrm{~h}$, and was lower at $12 \mathrm{~h}$ and $24 \mathrm{~h}$ (Figure 7a). On the contrary, the GhLOX2 expression level in TRV:GhOPR9 plants roots was lower than TRV:00 lines at $1 \mathrm{~h}$, and was higher at $12 \mathrm{~h}$ and $24 \mathrm{~h}$ (Figure $7 \mathrm{~b}$ ). In contrast, the expression levels of GhLOX3 andGhLOX6 had increasing trends in leaves (Figure 7a), but the GhLOX3 expression level was increased at $01 \mathrm{~h}$ and decreased from $12 \mathrm{~h}$ to $24 \mathrm{~h}$ in roots; the GhLOX6 expression level had a decreasing trend in roots (Figure $7 \mathrm{~b}$ ). In addition, these genes expression levels in TRV:GhOPR9 plants roots were lower than that in TRV:00 lines after V. dahliae inoculation, except the GhLOX2 expression pattern at $01 \mathrm{~h}$ (Figure $7 \mathrm{~b}$ ).

(a)

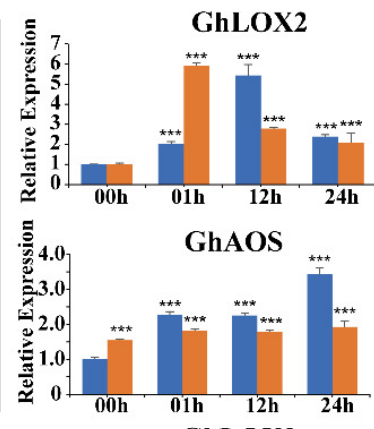

(b)
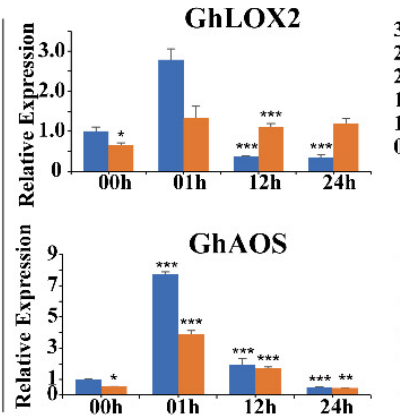
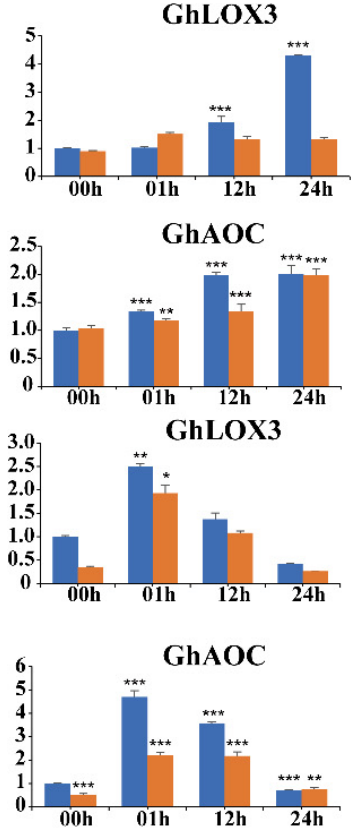
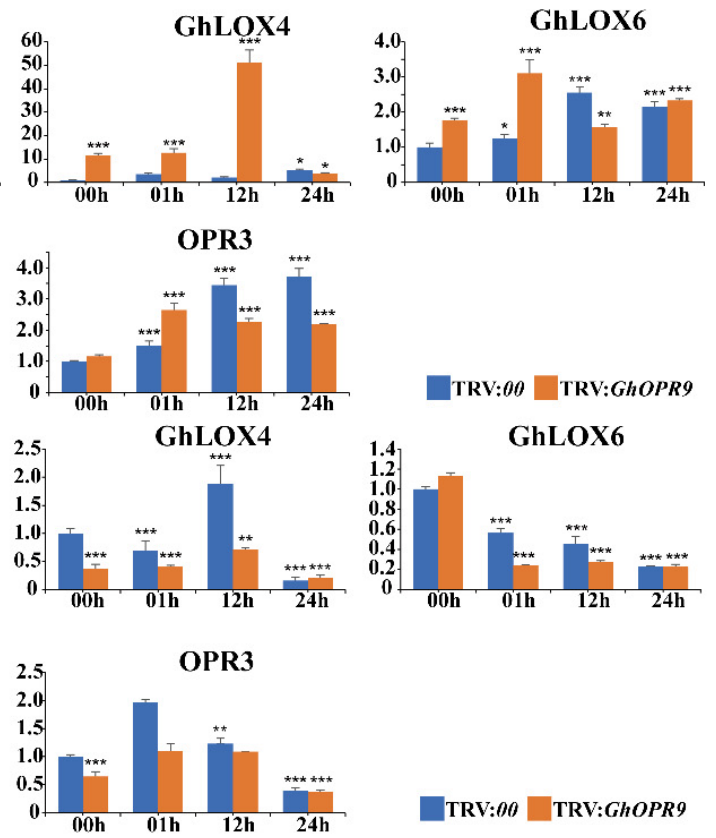

LTRV:00 TRV:GhOPR9

Figure 7. Real-time quantitative PCR analysis of the expression of JAs biosynthesis pathway genes at 00, 01, 12 and $24 \mathrm{~h}$ after Vd080 inoculation in the TRV:00 and TRV:GhOPR9 plants. (a) The expression levels of JAs biosynthesis pathway genes under Vd080 inoculation in leaf. (b) The expression levels of JAs biosynthesis pathway genes under Vd080 inoculation in root. Values represent means \pm standard deviation of three replicates. The TRV:00 plants $00 \mathrm{~h}$ were used as the control. Asterisks reveal the gene significantly higher or lower in other time points than in $00 \mathrm{~h}$ by $t$-test ${ }^{*} p<0.05,{ }^{* *} p<0.01$, *** $p<0.001)$.

\section{Discussion}

The OPR gene family was extensively presented in plants [21]. They had been well investigated in many plants. They were identified to be related to different physiological and biological functions. In rice, 13 OPR genes were uncovered, the OsOPR genes expression profiles were different in different tissues. The expression profiles were also different under different stresses. The OsOPRs might play multiple physiological and biological roles in rice [19]. In wheat, $48 O P R$ genes were identified. 
The TaOPRs showed diverse expression levels in response to various stresses, such as biotic (aphid), abiotic stress (wounding, salt, heat, drought) and exogenous hormone treatments (MeJA, ABA and JA) [20]. Among of the TaOPRs, TaOPR1 was involved in ABA signaling pathway and could enhance the reactive oxygen species scavenging to confer salinity tolerance [22]. TaOPR2 was related to the biosynthesis of JA [23]. In Z. mays, the maize genome encoded 8 OPR genes. ZmOPR1, ZmOPR2, $\mathrm{ZmOPR} 3, \mathrm{ZmOPR}$, and ZmOPR2 were in Group I, ZmOPR5, ZmOPR7 and ZmOPR8 were in Group II [16]. In cotton, previous study showed that the OPR3 of G. hirsutum was phosphorylated by GhCPK33 to suppress JA accumulation and JA signaling when host was infected by $V$. dahliae [27], and the other OPR genes were not studied explicitly. Though a genome-wide analysis of OPRs in cotton, we identified 10 OPR genes in G. hirsutum. According to our phylogenetic analysis, GhOPR genes were divided into two major groups in consistent with A. thaliana [14], and Group I was further classified into two subgroups in G. hirsutum. Compared to dicots, OPR genes were divided into five groups in monocots, such as wheat [20]. The previous study showed that lineage-specific expansion events occurred between higher and lower land plants [21]. Similarly, lineage-specific expansion events also occurred in higher land monocots (wheat), and extra three groups were generated after the divergence from dicots (cotton). Combined with the gene structure analysis, most of OPR genes in a group showed a similar exon/intron structure, indicating that the evolution might affect both gene function and gene structure $[47,48]$.

In fact, not only the structural diversity of gene family members was a mechanism for the evolution of multiple gene families, but also intron loss and gain could play an important role in generating structural diversity and complexity [49]. In this study, only GhOPR5 had two introns, and GhOPR10 had three introns, most of other OPR genes contained 4-6 introns. However, 33 of $48 \mathrm{TaOPRs}$ had less than three introns [20]. ZmOPR1, ZmOPR2, and ZmOPR3 had only one intron [16]. These results revealed that the intron loss events occurred in different plant lineages from cotton to wheat or maize. Furthermore, the intron loss and gain occurred from ancestral OPR genes to present individual OPR genes in individual plant lineage. As the same with the results of the gene structure analysis, most of OPRs in a subgroup shared conserved protein motifs. Almost all of the OPRs had the motif 1, motif 2, motif 3 , motif 4 , motif 5 , and motif 6 . They were corresponded to the beta/alpha barrel and might be related to the OPR conserved protein domain [20]. However, some OPR contained specific motif; for instance, in subgroup I, GhOPR1, GhOPR2, GhOPR5, and GhOPR9 had motif 12. Interestingly, these OPRs had the same expression patterns in leaves and roots under Vd080 infection. Among of 4 GhOPRs, GhOPR9 expression level was significantly increased. These results suggested that diversity of motif member and gene structure probably contributed to gene expression under stress. In order to respond to various stresses, the OPR genes probably formed various gene structures or protein motifs during the genome evolution in cotton under the selection pressures. Tandem duplication, segmental duplication and genome duplication contributed to expansion of gene families and genome evolution [50,51]. As the results showed, the collinear relationships of $O P R$ genes were strong in cotton. We found 7 WGD or segmental duplication OPR genes in G. hirsutum and G. barbadense, respectively. In comparison with the WGD/segmental duplication, we just found 2 tandem duplication OPR genes in G. hirsutum, GhOPR8 and GhOPR9. But in G. barbadense, there was no tandem duplication OPR gene. In this study, WGD/segmental duplication possible made more contribution to expansion of OPR gene family than the tandem duplication, and tandem duplication genes contributed to the new biological functions in cotton genome evolution [52].

According to the prediction of cis-acting regulatory elements, GhOPR might play a role in regulating various biological processes in cotton. The GhOPRs might have association with phytohormones stimulation, such as JA, MeJA, ABA, GA, SA, IAA, and ET. It could be explained that OPR genes were involved in various signal pathways to participate in plant growth, development, and defensive responses. In wheat, TaOPR1 and TaOPR2 were involved in ABA and JA signal pathways, respectively, and could be induced by various stresses [22,23]. The SIOPR3-RNAi plants failed to accumulate JA after wounding and reduced trichome formation and affected monoterpene and sesquiterpene production; 
thus, the defense of tomato (S. lycopersicum) to the specialist herbivore Manduca sexta was reduced [53]. These could be suggested that OPRs might joined in stress resistance via hormone signaling pathways. In this study, the GhOPRs were down-regulated in response to PEG stress, and up-regulated in response to $\mathrm{NaCl}$ stress. But in wheat, the TaOPRs were down-regulated under salt stress [20]. The OPRs genes exhibited opposite expression profiles under salt treatment, the results indicated that the functions of GhOPRs might be different between dicots and monocots under abiotic stresses. Under the biotic stress, all of GhOPRs were response to the Vd080 infection in leaf, root and stem. And the GhOPR9 expression was significantly upregulated in root. These results indicated that $O P R s$ regulated various responses to abiotic and biotic stresses, the mechanism of OPRs functions needed to be further investigated.

Verticillium wilt is the most destructive disease of cotton. About 200 dicotyledonous plant species are susceptible to this notorious pathogen. To date, there is no efficient chemical pesticide available for cotton Verticillium wilt, such as G. hirsutum as the cultivated cotton species, there are few germplasms that are immune or highly resistant to $V$. dahliae [54,55]. The battle between plants and pathogens promotes the evolution of various defense pathways in the host and the attack strategies of pathogens. In particular, JAs, SAs, and ET, as the essential defensive roles of primary defense hormones, have been well understood [56]. The elevation of JA accumulation is usually occurred within a few minutes or a few hours after wounding or pathogen infection [57]. In this study, the GhOPRs expression levels were decreased at $1 \mathrm{~h}$ after Vd080 infection in cotton leaves, except GhOPR1. Previous study showed that the antagonistic crosstalk between the JA and SA pathways were effective against pathogens [58]. In this study, GhOPRs expression levels displayed fluctuation in leaves from $0 \mathrm{~h}$ to $48 \mathrm{~h}$ after Vd080 inoculation. These results might be related to the crosstalk of JA and SA pathways. Previous study showed that JA signaling can promote susceptibility to hemibiotrophic pathogens [59]. And in cotton, JA is the key hormone regulating response to V. dahliae [60]. VIGS is a quick and powerful technique to assess the function of genes by transient post-transcriptional gene silencing [61]. Agrobacterium-mediated TRV-VIGS could be used in cotton leaves and fiber [62,63]. Silencing GhNDR1 and GhMKK2 via TRV-VIGS technique compromised the cotton resistance to Verticillium wilt [64]. Silencing GhCPK33 induced JA accumulation and enhanced resistance to V. dahliae [27]. GbWRKY1, GhCYP82D, GhLac1, and GhJAZ2 could modulate resistance to V. dahliae in cotton by regulating JA biosynthesis [65-68]. JA response-associated genes were upregulated in GhWRKY70-silenced cotton plants and could increase the resistance of cotton to $V$. dahliae [69]. In the present study, GhOPR9 silenced plants showed susceptibility to Vd080 infection, moreover, the expression levels of GhLOX3, GhLOX4, GhLOX6, GhAOS, GhAOC, and OPR3 of G. hirsutum, which were the upstream genes of OPR2 in silenced plants roots, were lower than the expression levels of these genes in TRV:00 plants root after Vd080 infection. These suggested that GhOPR9 might positively regulate the resistance of cotton to $V$. dahliae via mediated the JAs pathway genes. Furthermore, in susceptible G. hirsutum cv. Jimian No.11 (Supplemental Figure S2), GhOPR9-silenced lines displayed more susceptibility to Vd080 than the TRV:00 plants. Considering the tandem duplication of GhOPR9, GhOPR8 was also silenced by VIGS in Zhongzhimian No. 2 (Supplemental Figure S3). These tandem duplication genes maybe had the functional redundancy in regulating the JAs related genes to modulate the resistance of cotton to $V$. dahliae. However, the precise mechanism of the GhOPR9 function remains to be further studied.

\section{Conclusions}

In this study, a total of 19 OPR genes were identified in G. hirsutum and G. barbadense, which were classified into three groups. WGD or segmental duplication might play the principal role in the expansion of the OPR gene family in cotton. The cotton OPRs might be related to crucial processes-for instance, plant growth and development, phytohormone signal pathway, and defensive responses to various abiotic and biotic stresses. The expression patterns of OPR genes had PEG, $\mathrm{NaCl}$, and V. dahliae stress-responsive diversity. Furthermore, GhOPR9 positively regulated the resistance of cotton to $V$. dahliae via mediating the JAs pathway genes. This study can help us to have a better understanding 
of the OPR genes in cotton and can also help us to screen candidate genes with high resistance to V. dahliae.

Supplementary Materials: The following are available online at http://www.mdpi.com/2073-4425/11/10/1134/s1, Figure S1. Chromosomal localization of GhOPR and GbOPR genes. The 10 GhOPR members were distributed into five chromosomes in G. hirsutum. Nine GbOPR members were mapped on the five chromosomes in G. barbadense; Figure S2. GhOPR9 positively regulates cotton resistance against V. dahliae in susceptible G. hirsutum cv. Jimian No.11. (a) Disease symptoms of the TRV:00 and TRV:GhOPR9 plants after Vd080 inoculation. Photographs were taken at 21 days after inoculation. (b) The expression level of GhOPR9 in the TRV:00 and TRV:GhOPR9 plants. Total RNA was isolated from the TRV:00 and TRV:GhOPR9 plants roots after the TRV:GhPDS lines presented a photobleaching phenotype. GhUB7 was used as the reference. Each experiment was performed using three replicates. (c) Disease index of the TRV:00 and TRV:GhOPR9 plants at 12 days, 18 days, and 21 days after inoculation with Vd080. Each experiment was performed using three replicates. (d) qPCR analysis of the relative fungal biomass in stems of the TRV:00 and TRV:GhOPR9 plants at 21 days after Vd080 inoculation. Each experiment was performed using three replicates. Differences between groups were compared using the $t$-test $\left({ }^{*} p<0.05,{ }^{* *} p<0.01\right.$, $\left.{ }_{* * *} p<0.001\right)$; Figure S3. The expression level of GhOPR8 in the TRV:00 and TRV:GhOPR9 plants. Total RNA was isolated from the TRV:00 and TRV:GhOPR9 plants roots after the TRV:GhPDS lines presented a photobleaching phenotype. GhUB7 was used as the reference. Each experiment was performed using three replicates; Table S1. Primers used in this research work; Table S2. Details of the cotton OPR proteins physiochemical properties and gene annotation; Table S3. The named of different species OPR proteins; Table S4. The amino acid sequences of 15 conserved motifs; Table S5. Information of the homologous genes and the gene type of OPR genes in G. hirsutum and G. barbadense; Table S6. Details of cis-regulatory elements found in the $1.5 \mathrm{~kb}$ promoter region of the GhOPR genes.

Author Contributions: S.L., H.F., and H.Z. designed the experiment. S.L. and X.Z. implemented and collected the data. R.S. performed the bioinformatics analysis. S.L. analyzed the results and prepared the manuscript. S.L., R.S., X.Z., Z.F., F.W., L.Z. (Lihong Zhao), Y.Z., L.Z. (Longfu Zhu), H.F., and H.Z. revised the manuscript. All authors revised and approved the final manuscript.

Funding: This work was supported by the National Science Foundation of China (Grant No. 31701479).

Acknowledgments: We deeply appreciate the great support of all teachers and students in the research team throughout the research period.

Conflicts of Interest: The authors declare no conflict of interest.

\section{References}

1. Wasternack, C.; Hause, B. Jasmonates: Biosynthesis, perception, signal transduction and action in plant stress response, growth and development. An update to the 2007 review in Annals of Botany. Ann. Bot. 2013, 111, 1021-1058. [CrossRef] [PubMed]

2. Savchenko, T.; Kolla, V.A.; Wang, C.Q.; Nasafi, Z.; Hicks, D.R.; Phadungchob, B.; Chehab, W.E.; Brandizzi, F.; Froehlich, J.; Dehesh, K. Functional Convergence of Oxylipin and Abscisic Acid Pathways Controls Stomatal Closure in Response to Drought. Plant Physiol. 2014, 164, 1151-1160. [CrossRef] [PubMed]

3. Wasternack, C. Jasmonates: An update on biosynthesis, signal transduction and action in plant stress response, growth and development. Ann. Bot. Lond. 2007, 100, 681-697. [CrossRef] [PubMed]

4. Wasternack, C.; Strnad, M. Jasmonate signaling in plant stress responses and development-Active and inactive compounds. New Biotechnol. 2016, 33, 604-613. [CrossRef]

5. Agrawal, G.K.; Tamogami, S.; Han, O.; Iwahashi, H.; Rakwal, R. Rice octadecanoid pathway. Biochem. Biophys. Res. Commun. 2004, 317, 1-15. [CrossRef]

6. Liechti, R.; Gfeller, A.; Farmer, E.E. Jasmonate signaling pathway. Sci. Stke 2006, 2006, cm2. [CrossRef]

7. Szczegielniak, J. Wound signal transduction pathways in plants. Postepy Biochem. 2007, 53, 121-132.

8. Vick, B.A.; Zimmerman, D.C. Biosynthesis of Jasmonic Acid by Several Plant Species. Plant Physiol. 1984, 75, 458-461. [CrossRef]

9. Wasternack, C.; Hause, B. Jasmonates and octadecanoids: Signals in plant stress responses and development. Prog. Nucleic Acid. Res. Mol. Biol. 2002, 72, 165-221. [CrossRef]

10. Baker, A.; Graham, I.A.; Holdsworth, M.; Smith, S.M.; Theodoulou, F.L. Chewing the fat: Beta-oxidation in signalling and development. Trends Plant Sci. 2006, 11, 124-132. [CrossRef]

11. Schaller, F. Enzymes of the biosynthesis of octadecanoid-derived signalling molecules. J. Exp. Bot. 2001, 52, 11-23. [CrossRef] [PubMed]

12. Liechti, R.; Farmer, E.E. Jasmonate biochemical pathway. Sci. STKE 2006, 2006, cm3. [CrossRef] [PubMed] 
13. Schaller, F; Weiler, E.W. Molecular cloning and characterization of 12-oxophytodienoate reductase, an enzyme of the octadecanoid signaling pathway from Arabidopsis thaliana-Structural and functional relationship to yeast old yellow enzyme. J. Biol. Chem. 1997, 272, 28066-28072. [CrossRef] [PubMed]

14. Stintzi, A.; Browse, J. The Arabidopsis male-sterile mutant, opr3, lacks the 12-oxophytodienoic acid reductase required for jasmonate synthesis. Proc. Natl. Acad. Sci. USA 2000, 97, 10625-10630. [CrossRef]

15. Matsui, H.; Nakamura, G.; Ishiga, Y.; Toshima, H.; Inagaki, Y.; Toyoda, K.; Shiraishi, T.; Ichinose, Y. Structure and expression of 12-oxophytodienoate reductase (subgroup I) genes in pea, and characterization of the oxidoreductase activities of their recombinant products. Mol. Genet. Genom. 2004, 271, 1-10. [CrossRef]

16. Zhang, J.L.; Simmons, C.; Yalpani, N.; Crane, V.; Wilkinson, H.; Kolomiets, M. Genomic analysis of the 12-oxo-phytodienoic acid reductase gene family of Zea mays. Plant Mol. Biol. 2005, 59, 323-343. [CrossRef]

17. Breithaupt, C.; Kurzbauer, R.; Lilie, H.; Schaller, A.; Strassner, J.; Huber, R.; Macheroux, P.; Clausen, T. Crystal structure of 12-oxophytodienoate reductase 3 from tomato: Self-inhibition by dimerization. Proc. Natl. Acad. Sci. USA 2006, 103, 14337-14342. [CrossRef]

18. Xin, Z.J.; Zhang, J.; Ge, L.G.; Lei, S.; Han, J.J.; Zhang, X.; Li, X.W.; Sun, X.L. A putative 12-oxophytodienoate reductase gene CsOPR3 from Camellia sinensis, is involved in wound and herbivore infestation responses. Gene 2017, 615, 18-24. [CrossRef]

19. Li, W.Y.; Zhou, F.; Liu, B.; Feng, D.R.; He, Y.M.; Qi, K.B.; Wang, H.B.; Wang, J.F. Comparative characterization, expression pattern and function analysis of the 12-oxo-phytodienoic acid reductase gene family in rice. Plant Cell Rep. 2011, 30, 981-995. [CrossRef]

20. Mou, Y.; Liu, Y.; Tian, S.; Guo, Q.; Wang, C. Genome-Wide Identification and Characterization of the OPR Gene Family in Wheat (Triticum aestivum L.). Int. J. Mol. Sci. 2019, 20, 1914. [CrossRef]

21. Li, W.; Liu, B.; Yu, L.; Feng, D.; Wang, H.; Wang, J. Phylogenetic analysis, structural evolution and functional divergence of the 12-oxo-phytodienoate acid reductase gene family in plants. BMC Evol. Biol. 2009, 9, 90. [CrossRef]

22. Dong, W.; Wang, M.; Xu, F.; Quan, T.; Peng, K.; Xiao, L.; Xia, G. Wheat oxophytodienoate reductase gene TaOPR1 confers salinity tolerance via enhancement of abscisic acid signaling and reactive oxygen species scavenging. Plant Physiol. 2013, 161, 1217-1228. [CrossRef]

23. Wang, Y.K.; Yuan, G.L.; Yuan, S.H.; Duan, W.J.; Wang, P.; Bai, J.F.; Zhang, F.T.; Gao, S.Q.; Zhang, L.P.; Zhao, C.P. TaOPR2 encodes a 12-oxo-phytodienoic acid reductase involved in the biosynthesis of jasmonic acid in wheat (Triticum aestivum L.). Biochem. Biophys. Res. Commun. 2016, 470, 233-238. [CrossRef]

24. Pigolev, A.V.; Miroshnichenko, D.N.; Pushin, A.S.; Terentyev, V.V.; Boutanayev, A.M.; Dolgov, S.V.; Savchenko, T.V. Overexpression of Arabidopsis OPR3 in Hexaploid Wheat (Triticum aestivum L.) Alters Plant Development and Freezing Tolerance. Int. J. Mol. Sci. 2018, 19, 3989. [CrossRef]

25. Tani, T.; Sobajima, H.; Okada, K.; Chujo, T.; Arimura, S.I.; Tsutsumi, N.; Nishimura, M.; Seto, H.; Nojiri, H.; Yamane, H. Identification of the OsOPR7 gene encoding 12-oxophytodienoate reductase involved in the biosynthesis of jasmonic acid in rice. Planta 2008, 227, 517-526. [CrossRef]

26. Scalschi, L.; Sanmartin, M.; Camanes, G.; Troncho, P.; Sanchez-Serrano, J.J.; Garcia-Agustin, P.; Vicedo, B. Silencing of OPR3 in tomato reveals the role of OPDA in callose deposition during the activation of defense responses against Botrytis cinerea. Plant J. 2015, 81, 304-315. [CrossRef]

27. Hu, Q.; Zhu, L.; Zhang, X.; Guan, Q.; Xiao, S.; Min, L.; Zhang, X. GhCPK33 Negatively Regulates Defense against Verticillium dahliae by Phosphorylating GhOPR3. Plant Physiol. 2018, 178, 876-889. [CrossRef]

28. Han, Q.; Wu, F.; Wang, X.; Qi, H.; Shi, L.; Ren, A.; Liu, Q.; Zhao, M.; Tang, C. The bacterial lipopeptide iturins induce Verticillium dahliae cell death by affecting fungal signalling pathways and mediate plant defence responses involved in pathogen-associated molecular pattern-triggered immunity. Environ. Microbiol. 2015, 17, 1166-1188. [CrossRef]

29. Hu, Y.; Chen, J.D.; Fang, L.; Zhang, Z.Y.; Ma, W.; Niu, Y.C.; Ju, L.Z.; Deng, J.Q.; Zhao, T.; Lian, J.M.; et al. Gossypium barbadense and Gossypium hirsutum genomes provide insights into the origin and evolution of allotetraploid cotton. Nat. Genet. 2019, 51, 739-748. [CrossRef]

30. El-Gebali, S.; Mistry, J.; Bateman, A.; Eddy, S.R.; Luciani, A.; Potter, S.C.; Qureshi, M.; Richardson, L.J.; Salazar, G.A.; Smart, A.; et al. The Pfam protein families database in 2019. Nucleic Acids Res. 2019, 47, D427-D432. [CrossRef]

31. Finn, R.D.; Clements, J.; Eddy, S.R. HMMER web server: Interactive sequence similarity searching. Nucleic Acids Res. 2011, 39, W29-W37. [CrossRef] 
32. Camacho, C.; Coulouris, G.; Avagyan, V.; Ma, N.; Papadopoulos, J.; Bealer, K.; Madden, T.L. BLAST plus: Architecture and applications. BMC Bioinform. 2009, 10, Artn 421. [CrossRef]

33. Jones, P.; Binns, D.; Chang, H.Y.; Fraser, M.; Li, W.Z.; McAnulla, C.; McWilliam, H.; Maslen, J.; Mitchell, A.; Nuka, G.; et al. InterProScan 5: Genome-scale protein function classification. Bioinformatics 2014, 30, 1236-1240. [CrossRef]

34. Edgar, R.C. MUSCLE: Multiple sequence alignment with high accuracy and high throughput. Nucleic Acids Res. 2004, 32, 1792-1797. [CrossRef]

35. Kumar, S.; Stecher, G.; Li, M.; Knyaz, C.; Tamura, K. MEGA X: Molecular Evolutionary Genetics Analysis across Computing Platforms. Mol. Biol. Evol. 2018, 35, 1547-1549. [CrossRef]

36. Hu, B.; Jin, J.P.; Guo, A.Y.; Zhang, H.; Luo, J.C.; Gao, G. GSDS 2.0: An upgraded gene feature visualization server. Bioinformatics 2015, 31, 1296-1297. [CrossRef]

37. Bailey, T.L.; Boden, M.; Buske, F.A.; Frith, M.; Grant, C.E.; Clementi, L.; Ren, J.Y.; Li, W.W.; Noble, W.S. MEME SUITE: Tools for motif discovery and searching. Nucleic Acids Res. 2009, 37, W202-W208. [CrossRef]

38. Hao, Z.D.; Lv, D.K.; Ge, Y.; Shi, J.S.; Weijers, D.; Yu, G.C.; Chen, J.H. RIdeogram: Drawing SVG graphics to visualize and map genome-wide data on the idiograms. PeerJ Comput. Sci. 2020. [CrossRef]

39. Wang, Y.P.; Tang, H.B.; DeBarry, J.D.; Tan, X.; Li, J.P.; Wang, X.Y.; Lee, T.H.; Jin, H.Z.; Marler, B.; Guo, H.; et al. MCScanX: A toolkit for detection and evolutionary analysis of gene synteny and collinearity. Nucleic Acids Res. 2012, 40. [CrossRef]

40. Krzywinski, M.; Schein, J.; Birol, I.; Connors, J.; Gascoyne, R.; Horsman, D.; Jones, S.J.; Marra, M.A. Circos: An information aesthetic for comparative genomics. Genome Res. 2009, 19, 1639-1645. [CrossRef]

41. Li, T.G.; Wang, B.L.; Yin, C.M.; Zhang, D.D.; Wang, D.; Song, J.; Zhou, L.; Kong, Z.Q.; Klosterman, S.J.; Li, J.J.; et al. The Gossypium hirsutum TIR-NBS-LRR gene GhDSC1 mediates resistance against Verticillium wilt. Mol. Plant Pathol. 2019, 20, 857-876. [CrossRef]

42. Tang, Y.; Zhang, Z.N.; Lei, Y.; Hu, G.; Liu, J.F.; Hao, M.Y.; Chen, A.M.; Peng, Q.Z.; Wu, J.H. Cotton WATs Modulate SA Biosynthesis and Local Lignin Deposition Participating in Plant Resistance Against Verticillium dahliae. Front. Plant Sci. 2019, 10. [CrossRef]

43. Zhu, H.Q.; Feng, Z.L.; Li, Z.F.; Shi, Y.Q.; Zhao, L.H.; Yang, J.R. Characterization of Two Fungal Isolates from Cotton and Evaluation of their Potential for Biocontrol of Verticillium Wilt of Cotton. J. Phytopathol. 2013, 161, 70-77. [CrossRef]

44. Wei, F.; Zhao, L.H.; Xu, X.M.; Feng, H.J.; Shi, Y.Q.; Deakin, G.; Feng, Z.L.; Zhu, H.Q. Cultivar-Dependent Variation of the Cotton Rhizosphere and Endosphere Microbiome Under Field Conditions. Front. Plant Sci. 2019, 10. [CrossRef]

45. Luna, E.; Pastor, V.; Robert, J.; Flors, V.; Mauch-Mani, B.; Ton, J. Callose deposition: A multifaceted plant defense response. Mol. Plant Microbe. Interact. 2011, 24, 183-193. [CrossRef]

46. Ruan, J.J.; Zhou, Y.X.; Zhou, M.L.; Yan, J.; Khurshid, M.; Weng, W.F.; Cheng, J.P.; Zhang, K.X. Jasmonic Acid Signaling Pathway in Plants. Int. J. Mol. Sci. 2019, 20, 2479. [CrossRef]

47. Babenko, V.N.; Rogozin, I.B.; Mekhedov, S.L.; Koonin, E.V. Prevalence of intron gain over intron loss in the evolution of paralogous gene families. Nucleic Acids Res. 2004, 32, 3724-3733. [CrossRef]

48. Roy, S.W.; Penny, D. On the incidence of intron loss and gain in paralogous gene families. Mol. Biol. Evol. 2007, 24, 1579-1581. [CrossRef]

49. Zhang, Z.; Kishino, H. Genomic background predicts the fate of duplicated genes: Evidence from the yeast genome. Genetics 2004, 166, 1995-1999. [CrossRef]

50. Zhang, J.Z. Evolution by gene duplication: An update. Trends Ecol. Evol. 2003, 18, 292-298. [CrossRef]

51. Moore, R.C.; Purugganan, M.D. The evolutionary dynamics of plant duplicate genes. Curr. Opin. Plant Biol. 2005, 8, 122-128. [CrossRef]

52. Conant, G.C.; Wolfe, K.H. Turning a hobby into a job: How duplicated genes find new functions. Nat. Rev. Genet. 2008, 9, 938-950. [CrossRef]

53. Bosch, M.; Wright, L.P.; Gershenzon, J.; Wasternack, C.; Hause, B.; Schaller, A.; Stintzi, A. Jasmonic Acid and Its Precursor 12-Oxophytodienoic Acid Control Different Aspects of Constitutive and Induced Herbivore Defenses in Tomato. Plant Physiol. 2014, 166, 396-U574. [CrossRef]

54. Aguado, A.; De Los Santos, B.; Blanco, C.; Romero, F. Study of gene effects for cotton yield and Verticillium wilt tolerance in cotton plant (Gossypium hirsutum L.). Field Crop Res. 2008, 107, 78-86. [CrossRef] 
55. Zhang, J.F.; Sanogo, S.; Flynn, R.; Baral, J.B.; Bajaj, S.; Hughs, S.E.; Percy, R.G. Germplasm evaluation and transfer of Verticillium wilt resistance from Pima (Gossypium barbadense) to Upland cotton (G. hirsutum). Euphytica 2012, 187, 147-160. [CrossRef]

56. Kazan, K.; Lyons, R. Intervention of Phytohormone Pathways by Pathogen Effectors. Plant Cell 2014, 26, 2285-2309. [CrossRef]

57. Hettenhausen, C.; Yang, D.H.; Baldwin, I.T.; Wu, J. Calcium-dependent protein kinases, CDPK4 and CDPK5, affect early steps of jasmonic acid biosynthesis in Nicotiana attenuata. Plant Signal. Behav. 2013, 8, e22784. [CrossRef]

58. Lyons, R.; Manners, J.M.; Kazan, K. Jasmonate biosynthesis and signaling in monocots: A comparative overview. Plant Cell Rep. 2013, 32, 815-827. [CrossRef]

59. Oka, K.; Kobayashi, M.; Mitsuhara, I.; Seo, S. Jasmonic acid negatively regulates resistance to Tobacco mosaic virus in tobacco. Plant Cell Physiol. 2013, 54, 1999-2010. [CrossRef]

60. Shaban, M.; Miao, Y.; Ullah, A.; Khan, A.Q.; Menghwar, H.; Khan, A.H.; Ahmed, M.M.; Tabassum, M.A.; Zhu, L. Physiological and molecular mechanism of defense in cotton against Verticillium dahliae. Plant Physiol. Biochem. 2018, 125, 193-204. [CrossRef]

61. Senthil-Kumar, M.; Mysore, K.S. New dimensions for VIGS in plant functional genomics. Trends Plant Sci. 2011, 16, 656-665. [CrossRef] [PubMed]

62. Gao, X.; Britt, R.C., Jr.; Shan, L.; He, P. Agrobacterium-Mediated Virus-Induced Gene Silencing Assay in Cotton. J. Vis. Exp. 2011. [CrossRef] [PubMed]

63. Qu, J.; Ye, J.; Geng, Y.F.; Sun, Y.W.; Gao, S.Q.; Zhang, B.P.; Chen, W.; Chua, N.H. Dissecting functions of KATANIN and WRINKLED1 in cotton fiber development by virus-induced gene silencing. Plant Physiol. 2012, 160, 738-748. [CrossRef] [PubMed]

64. Gao, X.; Wheeler, T.; Li, Z.; Kenerley, C.M.; He, P.; Shan, L. Silencing GhNDR1 and GhMKK2 compromises cotton resistance to Verticillium wilt. Plant J. 2011, 66, 293-305. [CrossRef] [PubMed]

65. Li, C.; He, X.; Luo, X.; Xu, L.; Liu, L.; Min, L.; Jin, L.; Zhu, L.; Zhang, X. Cotton WRKY1 mediates the plant defense-to-development transition during infection of cotton by Verticillium dahliae by activating JASMONATE ZIM-DOMAIN1 expression. Plant Physiol. 2014, 166, 2179-2194. [CrossRef]

66. Sun, L.; Zhu, L.; Xu, L.; Yuan, D.; Min, L.; Zhang, X. Cotton cytochrome P450 CYP82D regulates systemic cell death by modulating the octadecanoid pathway. Nat. Commun. 2014, 5, 5372. [CrossRef]

67. Hu, Q.; Min, L.; Yang, X.; Jin, S.; Zhang, L.; Li, Y.; Ma, Y.; Qi, X.; Li, D.; Liu, H.; et al. Laccase GhLac1 Modulates Broad-Spectrum Biotic Stress Tolerance via Manipulating Phenylpropanoid Pathway and Jasmonic Acid Synthesis. Plant Physiol. 2018, 176, 1808-1823. [CrossRef]

68. He, X.; Zhu, L.; Wassan, G.M.; Wang, Y.; Miao, Y.; Shaban, M.; Hu, H.; Sun, H.; Zhang, X. GhJAZ2 attenuates cotton resistance to biotic stresses via inhibiting the transcriptional activity of GhbHLH171. Mol. Plant Pathol. 2017, 19, 896-908. [CrossRef]

69. Xiong, X.P.; Sun, S.C.; Li, Y.J.; Zhang, X.Y.; Sun, J.; Xue, F. The cotton WRKY transcription factor GhWRKY70 negatively regulates the defense response against Verticillium dahliae. Crop J. 2019, 7, 393-402. [CrossRef]

(C) 2020 by the authors. Licensee MDPI, Basel, Switzerland. This article is an open access article distributed under the terms and conditions of the Creative Commons Attribution (CC BY) license (http://creativecommons.org/licenses/by/4.0/). 